\title{
Productivity and international competitiveness of agriculture in the European Union and the United States
}

\author{
V. Eldon Balla,*, Jean-Pierre Butault ${ }^{\mathrm{b}}$, Carlos San Juan ${ }^{\mathrm{c}}$, Ricardo Mora ${ }^{\mathrm{c}}$ \\ ${ }^{a}$ ERS-USDA, 1800 M Street, NW, Washington, DC 20036-5831, USA \\ ${ }^{\mathrm{b}}$ INRA AgroParisTech, Laboratoire d'Economie Publique, 16 rue Claude Bernard, Paris, France \\ ${ }^{\mathrm{c}}$ Department of Economics, Universidad Carlos III de Madrid, Madrid, Spain
}

\begin{abstract}
This study looks at international competitiveness of agriculture in the European Union and the United States. The most intuitive concept is that of price competitiveness. We calculate relative prices for 11 member states of the European Union and the United States for the period 1973-2002. We assume that markets are perfectly competitive and in long-run equilibrium, so that the observed price always equals average total cost, as measured by the cost dual to the production function. This assumption is used in our calculation of relative competitiveness and productivity gaps between the European Union and the United States and in our decomposition of relative price movements between changes in relative input prices and changes in relative productivity levels.
\end{abstract}

JEL classifications: Q16, Q17

Keywords: Agriculture; International competitiveness; Relative output and input prices; Relative productivity levels; European Union; United States

\section{Introduction}

The Doha Round of trade negotiations has stagnated, with the European Union and the United States at an impasse over the level of support for agriculture and the need for increased market access. ${ }^{1}$ These "trade frictions" have accompanied the rapid expansion of agricultural exports to the United States. ${ }^{2}$ Explanations for the resulting trade imbalance must include variations in exchange rates, changes in the relative prices of factors of production, and the relative growth of productivity in European and U.S. agriculture. ${ }^{3}$ We analyze the role of each

\footnotetext{
*Corresponding author. Tel.: 202-694-5601; fax 202-694-5756.

E-mail address: eball@ers.usda.gov (V. E. Ball).

${ }^{1}$ While policy differences between the United States and the European Union were an impediment to successful completion of the Doha Round, the reluctance of developing countries to open their markets in return for a reduction in U.S. support for agriculture proved a more intractable problem.

${ }^{2}$ The U.S. trade surplus in bulk commodities reached $\$ 10$ billion in 1981. But the rapid expansion in European exports-increasing from $\$ 238$ million in 1981 to nearly $\$ 2$ billion in 2005-reduced this surplus to $\$ 2.5$ billion in 2005 . If the value of trade in processed items is included, the $\$ 2.5$ billion surplus becomes a $\$ 5$ billion trade deficit (Source: U.S. Department of Commerce, Bureau of the Census).

${ }^{3}$ There are other factors in addition to those elicited here. These include nontariff barriers to trade (e.g., hormone-beef, GM maize moratorium, etc.),
}

of these factors in explaining the rise in competitiveness of European Union agriculture relative to the United States.

At the outset of the discussion it is essential to define a measure of international competitiveness. Our measure of international competitiveness is the price of output in a given country relative to the price in the United States. ${ }^{4}$ We calculate relative output prices for 11 member states of the European UnionBelgium, Denmark, Germany, Greece, Spain, France, Ireland, Italy, the Netherlands, Sweden, and the United Kingdomfor the period 1973-2002. ${ }^{5}$ In order to explain changes in

growth in trade with other countries (e.g., Asia) to the detriment of transatlantic trade, changes in the composition of trade, and enlargement of the European Union, potentially displacing trade with the United States. Last, incomes in the United States have grown more rapidly then in the European Union for much of the study period. All of these factors likely played a role in the decreased United States terms of trade with Europe.

${ }^{4}$ This measure of competitiveness is common to the literature on general equilibrium. If production exhibits constant returns to scale, as is assumed in this study, then equilibrium requires that the price of output equals unit cost. Hence, it can be viewed as a measure of the relative cost of production.

${ }^{5}$ The present-day European Union (EU) was founded by six nationsBelgium, France, Federal Republic of Germany (West Germany), Italy, the Netherlands, and Luxembourg — that signed the Treaty of Rome in 1959. Three additional countries — Denmark, Ireland, and the United Kingdom-joined in 1973. Greece became a full member in 1981, Portugal and Spain in 1986, and 
international competitiveness, we must account for changes in the determinants of this relative price.

The starting point for our analysis of the competitiveness of European and United States agriculture is the exchange rate between each national currency and the dollar. Variations in exchange rates are easy to document and are often used to characterize movements in relative prices among countries. However, movements in these relative prices of goods and services do not coincide with variations in exchange rates. To account for changes in international competitiveness a measure of the relative prices of specific goods and services is required.

Relative prices between European and U.S. agriculture can be summarized by means of purchasing power parities. The purchasing power parity for a specific industry's output is defined as the number of units of a given currency required to purchase the same amount of goods as a unit of the numeraire currency. The dimensions of the purchasing power parities are the same as the exchange rate. However, the purchasing power parities reflect the relative prices of the goods and services that make up the industry's output in each country.

In this study, we construct purchasing power parities for agriculture in the 11 European countries and the United States for the period 1973-2002. These are relative prices of industry output in each country expressed in terms of national currencies per dollar. We divide the relative output prices by the exchange rate to translate the purchasing power parities into relative prices in dollars. We employ relative prices denominated in dollars as our measure of international competitiveness. Variations in exchange rates are reflected in the relative prices of output in all 12 countries.

To account for changes in international competitiveness among the 11 European countries and the United States, we have constructed purchasing power parities for the inputs employed in agriculture. By analogy with output, the purchasing power parities for inputs are based on the relative prices of the goods and services that make up the inputs. We have disaggregated inputs among capital, land, and labor services, which are primary factors of production, and intermediate goods, which are produced by other industries and consumed by the agricultural industry. We can translate the purchasing power parities for inputs into relative prices in dollars by dividing by the exchange rate.

The final step in accounting for changes in international competitiveness is to measure relative levels of productivity for all 12 countries in the comparison. We employ a multilateral model of production. This model enables us to express the price of output in each country as a function of the prices of the inputs and the level of productivity in that country. We can account for the relative prices of output among countries by allowing input prices and levels of productivity to differ among countries. We have compiled data on relative productivity levels in the

Austria, Finland, and Sweden in 1995, completing the EU-15. Three of these countries-Austria, Finland, and Portugal-were excluded from the analysis because of missing data.
11 European countries and the United States for the period 1973-2002. For this purpose, we have revised and extended the estimates for 1973-1993 reported by Ball et al. (2001). A number of studies have reported productivity growth rates in European and U.S. agriculture (Arnade, 1995; Coelli and Prasada Rao, 2003; Gopinath et al., 1997), but the study by Ball et al. (2001) is the only study to provide a farm-sector comparison of relative levels of productivity.

The methodology for this study was developed by Jorgenson and Nishimizu (1978). They provided a theoretical framework for productivity comparisons based on a bilateral production function. They employed this framework in comparing output, input, and productivity at the aggregate level for Japan and the United States. The methodology was extended to the industry level by Jorgenson and Nishimizu (1981). The industry-level approach introduced models of production for individual industries based on bilateral production functions for each industry. A brief discussion of the theoretical framework for international comparisons is provided in the next section of this article.

In subsequent sections, we describe the product and factor accounts for European and U.S. agriculture. These accounts underpin our estimates of relative output and input prices and relative levels of total factor productivity. We employ changes in relative productivity levels and relative prices of inputs in accounting for changes in international competitiveness. The final section provides a summary of results and conclusions.

\section{Theoretical framework}

Under competitive conditions, we can represent the production technology by a price function that is dual to a linearly homogeneous production function for all 12 countries (Samuelson, 1953; Shephard, 1953, 1970)

$$
\begin{aligned}
\ln P= & \alpha_{0}+\sum_{i} \alpha_{i} \ln W_{i}+\alpha_{t} T+\sum_{d} \alpha_{d} D_{d} \\
& +\frac{1}{2} \sum_{i} \sum_{j} \beta_{i j} \ln W_{i} \ln W_{j}+\sum_{i} \beta_{i t} \ln W_{i} T \\
& +\sum_{i} \sum_{d} \beta_{i d} \ln W_{i} D_{d}+\frac{1}{2} \beta_{t t} T^{2} \\
& +\sum_{d} \beta_{t d} T D_{d}+\frac{1}{2} \sum_{d} \beta_{d d} D_{d}^{2},
\end{aligned}
$$

where $P$ is the price of industry output in each country, the $W_{i}$ are input prices, $T$ is time, $D_{d}$ is a dummy variable equal to one for the corresponding country and zero otherwise, and $d$ is an index of countries, running over Belgium, Denmark, Germany, Greece, Spain, France, Ireland, Italy, the Netherlands, Sweden, and the United Kingdom. Since we express levels of output and input prices and levels of productivity relative to the United States, we omit a dummy variable for the United States from the price function. Since $T$ and $D_{d}$ interact with input prices, differences in levels of productivity across time and across countries are permitted to be nonneutral. 
In examining the differences in production patterns among countries, we combine the price function with the demand functions for inputs. We can express these functions as equalities between the share of each input in the value of output and the elasticity of the output price with respect to the price of that input $^{6}$

$v_{X_{i}}=\frac{\partial \ln P}{\partial \ln W_{i}}[W, T, D]=\alpha_{i}+\sum_{j} \beta_{i j} \ln W_{j}+\beta_{i t} T+\beta_{i d} D_{d}$

The sum of the elasticities with respect to all inputs equals unity, so that the value shares also sum to unity. ${ }^{7}$

We can define the rate of productivity growth, say $v_{T}$, as the negative of the rate of growth of the output price with respect to time, holding input prices and the country dummy variables constant

$-v_{T}=\frac{\partial \ln P}{\partial T}[P, T, D]=\alpha_{t}+\sum_{i} \beta_{i t} \ln W_{i}+\beta_{t t} T+\beta_{t d} D_{d}$.

Similarly, we can define the difference in productivity between any country and the United States, say $v_{D}$, as the negative of the logarithmic derivative of the level of the output price with respect to the dummy variable representing differences in productivity between the countries, holding input prices and time constant

$-v_{D}=\frac{\partial \ln P}{\partial D_{d}}[P, T, D]=\alpha_{d}+\beta_{i d} \ln W_{i}+\beta_{t d} T+\beta_{d d} D_{d}$.

Our empirical application does not involve estimating the parameters of the price function; rather, we use index numbers that are exact for the translog specification. This approach was followed by Jorgenson and Nishimizu (1978, 1981) in their bilateral comparisons of output, input, and productivity for the United States and Japan. The average rate of productivity growth between two discrete points of time, say $T$ and $T-1$, can be expressed as the difference between a weighted average of growth rates of input prices and the growth rates of the price of output for each country

$$
\begin{aligned}
-\bar{v}_{T}= & \ln P(T)-\ln P(T-1) \\
& -\sum_{i} \bar{v}_{X_{i}}\left[\ln W_{i}(T)-\ln W_{i}(T-1)\right],
\end{aligned}
$$

where the average rate of technical change is

$\bar{v}_{T}=\frac{1}{2}\left[v_{T}(T)+v_{T}(T-1)\right]$,

\footnotetext{
${ }^{6}$ Equation (2) gives the necessary conditions for producer equilibrium in each country. We use the envelope theorem (Shephard's lemma) to obtain the factor demands, but because Eq. (1) is in logs we obtain the share of each input in the value of output.

${ }^{7}$ This follows from application of Euler's theorem to a linearly homogeneous function.
}

and the weights are given by the average value shares

$\bar{v}_{X_{i}}=\frac{1}{2}\left[v_{X_{i}}(T)+v_{X_{i}}(T-1)\right]$.

The index number defined by Eq. (5) is the translog price index of productivity change suggested by Jorengenson and Griliches (1967). ${ }^{8}$ Diewert (1976) showed that the index is exact for the translog price function.

The difference in productivity between any two countries, say $\hat{v}_{D}$, can be expressed as weighted averages of the differences between logarithms of the input prices for each country and the geometric mean of input prices over all 12 countries, less the difference between logarithms of the output price. Expressing differences in productivity relative to the United States

$$
\begin{aligned}
-\hat{v}_{D}= & \ln P(d)-\ln P(U S)-\sum_{i} \hat{v}_{X_{i}}(d)\left[\ln W_{i}(d)-\overline{\ln W_{i}}\right] \\
& +\sum_{i} \hat{v}_{X_{i}}(U S)\left[\ln W_{i}(U S)-\overline{\ln W_{i}}\right]
\end{aligned}
$$

where

$\hat{v}_{X_{i}}(d)=\frac{1}{2}\left[v_{X_{i}}(d)+\frac{1}{N} \sum_{d} v_{X_{i}}(d)\right]$,

and a bar indicates the average over all $N$ countries.

The translog index of productivity differences defined by Eq. (6) was introduced by Caves, Christensen, and Diewert (1982). Its use for making bilateral comparisons results in transitive multilateral comparisons that retain a high degree of characteristicity. ${ }^{9}$

To complete the methodology for comparing levels of output and input prices and levels of productivity among countries, we require specific forms for the functions defining the price of aggregate output and the prices of capital, land, labor, and materials inputs. We specify the price of output as a linearly homogeneous translog function of the prices of the components of output for all 12 countries $^{10}$

$\ln P=\sum_{i} \alpha_{i} \ln P_{i}+\frac{1}{2} \sum_{i} \sum_{j} \beta_{i j} \ln P_{i} \ln P_{j}$.

We can define the shares of these components in the value of total output by

$v_{Y_{i}}=\frac{\partial \ln P}{\partial \ln P_{i}}[P, T, D]=\alpha_{i}+\sum_{j} \beta_{i j} \ln P_{j}$.

\footnotetext{
${ }^{8}$ The measure of productivity defined by Eq. (5) makes sense only if revenue equals costs in each period. This is an assumption that we make. Diewert (1992) has shown that under this assumption the price index of productivity change equals the more familiar quantity index of productivity growth.

${ }^{9}$ The term characteristicity was coined by Drechsler (1973). It indicates the degree to which index number weights reflect the economic conditions that are specific to the two countries being compared.

${ }^{10}$ Assume that optimizing agents choose combinations of outputs $Y_{j}$ to maximize revenue associated with aggregate output $Y$. The result is a unit revenue function that is Eq. (7) with all of the envelope properties.
} 
Since the price of output is a translog function of the prices of its components, the difference between successive logarithms of the price of output can be expressed as a weighted average of differences between logarithms of component prices with weights given by the average value shares

$\ln P(T)-\ln P(T-1)=\sum_{i} \bar{v}_{Y_{i}}\left[\ln P_{i}(T)-\ln P_{i}(T-1)\right]$,

where

$\bar{v}_{Y_{i}}=\frac{1}{2}\left[v_{Y_{i}}(T)+v_{Y_{i}}(T-1)\right]$.

Similarly, considering data for all 12 countries at a given point of time, the difference between logarithms of the price of output for any two countries can be expressed as weighted averages of the differences between logarithms of the component prices and the geometric average of component prices for the 12 countries. Expressing the differences in output prices relative to the United States

$$
\begin{aligned}
\ln P(d)-\ln P(U S)= & \sum_{i} \hat{v}_{Y_{i}}(d)\left[\ln P_{i}(d)-\overline{\ln P_{i}}\right] \\
& -\sum_{i} \hat{v}_{Y_{i}}(U S)\left[\ln P_{i}(U S)-\overline{\ln P_{i}}\right]
\end{aligned}
$$

where

$\hat{v}_{Y_{i}}(d)=\frac{1}{2}\left[v_{Y_{i}}(d)+\frac{1}{N} \sum_{d} v_{Y_{i}}(d)\right]$,

and

$\overline{\ln P_{i}}=\frac{1}{N} \sum_{d} \ln P_{i}(d)$.

The price index in Eq. (10) represents the purchasing power parity between the currencies of the two countries expressed in terms of agricultural output.

If the input prices are translog functions of their components for all 12 countries, we can express the differences between successive logarithms of input prices for a given country as

$\ln W_{i}(T)-\ln W_{i}(T-1)=\sum_{j} \bar{v}_{X_{i j}}\left[\ln W_{i j}(T)-\ln W_{i j}(T-1)\right]$,

where

$\bar{v}_{X_{i j}}=\frac{1}{2}\left[v_{X_{i j}}(T)+v_{X_{i j}}(T-1)\right]$,

and $v_{X_{i j}}$ are the shares of the components in the value of the input aggregates.

Finally, we can express the differences between logarithms of input prices relative to the United States as

$$
\begin{aligned}
\ln W_{i}(d)-\ln W_{i}(U S)= & \sum_{j} \hat{v}_{X_{i j}}(d)\left[\ln W_{i j}(d)-\overline{\ln W_{i j}}\right] \\
& -\sum_{j} \hat{v}_{X_{i j}}(U S)\left[\ln W_{i j}(U S)-\overline{\ln W_{i j}}\right]
\end{aligned}
$$

where

$\hat{v}_{X_{i j}}(d)=\frac{1}{2}\left[v_{X_{i j}}(d)+\frac{1}{N} \sum_{d} v_{X_{i j}}(d)\right]$

and

$\overline{\ln W_{i j}}=\frac{1}{N} \sum_{d} \ln W_{i j}(d)$.

The price indexes in Eq. (12) represent the purchasing power parities expressed in terms of the inputs employed in agriculture.

\section{Data}

We assume that data on production patterns in the 11 European countries and the United States are generated by a gross output model of production. Output is defined as gross production leaving the farm, as opposed to real value added. Inputs are not limited to labor and capital, but include intermediate inputs as well. The text in this section provides an overview of the sources and methods used to construct the product and factor accounts for the period 1973-2002 for each of the 12 countries. ${ }^{11}$ A technical appendix providing a complete, detailed description of the data is available from the authors upon request.

\subsection{Output and intermediate input}

Our measure of agricultural output includes deliveries to final demand and to intermediate demand in the nonfarm sector. We also include deliveries to intermediate farm demand so long as these deliveries are intended for different production activities (e.g., crop production intended for use in animal feeding).

An unconventional aspect of our measure of total output is the inclusion of output from "inseparable" secondary activities. These activities are defined as activities whose costs cannot be observed separately from those of the primary agricultural activity. Two types of secondary activities are distinguished. The first represents a continuation of the agricultural activity, such as the processing and packaging of agricultural products on the farm, while services relating to agricultural production, such as machine services for hire, are typical of the second.

The total output of the sector represents the sum of output of agricultural goods and the output of goods and services from secondary activities. We evaluate industry output from the point of view of the producer; that is, subsidies are added and indirect

\footnotetext{
${ }^{11}$ The accounting framework is that proposed in Manual on the Economic Accounts for Agriculture and Forestry (Eurostat, 2000). This approach ensures consistency of the accounts across countries and, hence, facilitates international comparisons.
} 
taxes are subtracted from market values. ${ }^{12}$ In those countries where a forfeit system prevails, the difference between payments and refunds of the tax on value added (or VAT) is also included in the value of output.

Intermediate input consists of all goods and services consumed during the accounting period, excluding fixed capital. Those goods and services that are produced and consumed within the agricultural sector are included in intermediate input so long as they also enter the farm output accounts. The value of intermediate input includes taxes (other than the deductible VAT) less subsidies, whether paid to suppliers of intermediate goods or to agricultural producers. ${ }^{13}$

\subsection{Capital input}

The measurement of capital input begins with data on the stock of capital for each component of capital input, based on investments in constant prices. ${ }^{14}$ At each point of time the stock of capital, say $K(T)$, is the sum of all past investments, say $I(T-\tau)$, weighted by the relative efficiencies of capital goods of each age $\tau$, say $S(\tau)$

$K(T)=\sum_{\tau=0}^{\infty} S(\tau) I(T-\tau)$.

To estimate capital stock, we must introduce an explicit description of the decline in efficiency. This function, $S$, may be expressed in terms of two parameters, the service life of the asset $L$ and a curvature or decay parameter $\beta$. One possible form of the efficiency function is given by

$$
\begin{array}{ll}
S(\tau)=(L-\tau) /(L-\beta \tau), & 0 \leq \tau \leq L), \\
S(\tau)=0, & (\tau>L) .
\end{array}
$$

This function is a form of a rectangular hyperbola that provides a general model incorporating several types of depreciation as special cases.

The value of $\beta$ is restricted only to values less than or equal to one. For values of $\beta$ greater than zero, the function $S$ approaches

\footnotetext{
12 Among the European countries, output is valued at basic prices. The "basic price" is the price received by the producer from the purchaser for a unit of a good or service produced as output minus any tax paid on that unit as a consequence of its production or sale (i.e., taxes on production) plus any subsidy received on that unit as a consequence of its production or sale (i.e., subsidies on products) (Eurostat, 2000, p. 43).

13 The data on output and intermediate input for the European countries are from the Economic Accounts for Agriculture NewCronos database http://epp.eurostat.ec.europa.eu/. Comparable data for the United States can be downloaded from the USDA website www.ers.usda.gov/data/agproductivity/.

${ }^{14}$ Data on investment for the European countries are from Capital Stock Data for the European Union (Beutel, 1997). The series was extended through 2002 using Eurostat's NewCronos database http://europa.eu.int/comm/eurostat/ newcronos/. Data for the United States are from Fixed Reproducible Tangible Wealth in the United States (U.S. Dept. of Commerce, 2003) and are available online at the U.S. Department of Commerce website www.bea.gov/national/ FA2004/SelectTable.ASP\#52.
}

zero at an increasing rate. For values less than zero, $S$ approaches zero at a decreasing rate.

Little empirical evidence is available to suggest a precise value for $\beta$. However, two studies (Penson et al., 1977; Romain et al., 1987) provide evidence that efficiency decay occurs more rapidly in the later years of service, corresponding to a value of $\beta$ in the zero-one interval. For purposes of this study, it is assumed that the efficiency of a structure declines very slowly over most of its service life. The decay parameter for machinery and transportation equipment assumes that the decline in efficiency is more uniformly distributed over the asset's service life. Given these assumptions, the final $\beta$ values chosen were 0.75 for structures and 0.5 for machinery and equipment.

The other variable in the efficiency function is the asset lifetime $L$. For each asset type, there exists some mean service life $\bar{L}$ around which there exists a distribution of actual service lives. In order to determine the amount of capital available for production, the actual service lives and the relative frequency of assets with these lives must be determined. It is assumed that this distribution may be accurately depicted by the normal distribution truncated at points two standard deviations before and after the mean service life.

Once the frequency of a true service life $L$ is known, the decay function for that particular service life is calculated using the assumed value of $\beta$. This process is repeated for all other possible values of $L$. An aggregate efficiency function is then constructed as a weighted sum of individual efficiency functions using as weights the frequency of occurrence. This function not only reflects changes in efficiency, but also the discard distribution around the mean service life.

Firms undertaking investment decisions should add to capital stock if the present value of the net revenue generated by an additional unit of capital exceeds the purchase price of the asset. Stated algebraically, this condition is

$\sum_{t=1}^{\infty}\left(P \frac{\partial Y}{\partial K}-W_{K} \frac{\partial R_{t}}{\partial K}\right)(1+r)^{-t}>W_{K}$,

where $P$ is the price of output, $W_{K}$ is the price paid for a new unit of capital, $R_{t}$ is replacement investment, and $r$ is the real discount rate.

To maximize net worth, firms will add to capital stock until Eq. (15) holds as an equality

$P=\frac{\partial Y}{\partial K}=r W_{K} \sum_{t=1}^{\infty} W_{K} \frac{\partial R_{t}}{\partial K}\left((1+r)^{-t}=c\right.$,

where $c$ is the implicit rental price of capital.

The rental price consists of two components. The first term, $r W_{K}$, represents the opportunity cost associated with the initial investment. The second term, $r \sum_{t=1}^{\infty} W_{K} \frac{\partial R_{t}}{\partial K}(1+r)^{-t} s$, is the present value of the cost of all future replacements required to maintain the productive capacity of the capital stock.

We can simplify the expression for the rental price in the following way. Let $F$ denote the present value of the stream of 
capacity depreciation on one unit of capital according to the mortality distribution $m$

$F=\sum_{\tau=1}^{\infty} m(\tau)(1+r)^{-\tau}$

where $m(\tau)=-[S(\tau)-S(\tau-1)],(\tau=1,2, \ldots, L)$. It can be shown that

$\sum_{t=1}^{\infty} \frac{\partial R_{t}}{\partial K}(1+r)^{-t}=\sum_{t=1}^{\infty} F^{t}=\frac{F}{(1-F)}$,

so that

$c=\frac{r W_{K}}{(1-F)} \cdot{ }^{15}$

The real rate of return $r$ in Eq. (19) is calculated as the nominal yield on government bonds less the rate of inflation as measured by the implicit deflator for gross domestic product. ${ }^{16}$ An ex ante rate is obtained by expressing observed real rates as an ARIMA process. ${ }^{17}$ We then calculate $F$ holding the required real rate of return constant for that vintage of capital goods. In this way, implicit rental prices $c$ are calculated for each asset type.

Although we estimate the decline in efficiency of capital goods for each component of capital input separately for all 12 countries, we assume that the relative efficiency of new capital goods is the same in each country. The appropriate purchasing power parity for new capital goods is the purchasing power parity for the corresponding component of investment goods output (OECD, 1999, p. 162). To obtain the purchasing power parity for capital input, we multiply the purchasing power parity for investment goods for any country by the ratio of the price of capital input in that country relative to the United States.

\footnotetext{
${ }^{15}$ A number of European countries offer subsidies on purchases of new capital goods at the rate $s$ of their price, in which case the rental price falls to

$c=\left[r W_{K} /(1-F)\right](1-s)$.

Hence, the cost of capital services falls by $s$. To fully realize the reduction in capital costs made possible by the subsidy, the firm would have to sell its existing capital stock and replace it with new units of capital that are eligible for the subsidy. In a simple model with no adjustment costs and perfect resale markets, this would be possible. The subsidy would create a one-time capital loss on existing capital. The prices of used capital goods would have to decline to keep services from them competitive with the lower cost of services available from subsidized, new capital goods.

${ }^{16}$ The nominal rate was taken to be the average annual yield over all maturities.

${ }^{17}$ Ex ante real rates are expressed as an AR(1) process. We use this specification after examining the correlation coefficients for autocorrelation, partial and inverse autocorrelation, and performing the unit root and white noise tests. We centered each time series by subtracting its sample mean. The analysis was performed on the centered data.
}

\subsection{Land input}

To estimate the stock of land in each country, we construct translog price indexes of land in farms. The stock of land is then constructed implicitly as the ratio of the value of land in farms to the translog price index. The rental price of land is obtained using Eq. (19), assuming zero replacement.

Spatial differences in land characteristics or quality prevent the direct comparison of observed prices. To account for these differences, indexes of relative prices of land are constructed using hedonic regression methods in which a good is viewed as a bundle of characteristics that contribute to the productivity derived from its use. According to the hedonic framework the price of a good represents the valuation of the characteristics "that are bundled in it," and each characteristic is valued by its "implicit" price (Rosen, 1974). These prices are not observed directly and must be estimated from the hedonic price function.

A hedonic price function expresses the price of a good or service as a function of the quantities of the characteristics it embodies. Thus, the hedonic price function for land may be expressed as $W_{L}=W(X, D)$, where $W_{L}$ represents the price of land, $X$ is a vector of characteristics, and $D$ is a vector of other variables.

The World Soil Resources Office of the U.S. Department of Agriculture's Natural Resource Conservation Service has compiled data on characteristics that capture differences in land quality. ${ }^{18}$ These characteristics include soil acidity, salinity, and moisture stress, among others.

In areas with moisture stress, agriculture is not possible without irrigation. Hence irrigation (i.e., the percentage of the cropland that is irrigated) is included as a separate variable. Because irrigation mitigates the negative impact of acidity on plant growth, the interaction between irrigation and soil acidity is included in the vector of characteristics.

In addition to environmental attributes, we also include a "population accessibility" score for each region in each country. These indexes are constructed using a gravity model of urban development, which provides a measure of accessibility to population concentrations (Shi et al., 1997). A gravity index accounts for both population density and distance from that population. The index increases as population increases and/or distance from the population center decreases.

Other variables (denoted by $D$ ) are also included in the hedonic equation, and their selection depends not only on the underlying theory but also on the objectives of the study. If the main objective of the study is to obtain price indexes adjusted for quality, as in our case, the only variables that should be included in $D$ are country dummy variables, which will capture all price effects other than quality. After allowing for differences in the levels of the characteristics, the part of the price

\footnotetext{
${ }^{18}$ See Eswaren et al. (2003). They develop a procedure for evaluating inherent land quality and use this procedure to assess land resources on a global scale. Given the Eswaren, Beinroth, and Reich database, we use GIS to overlay country and regional boundaries. The result of the overlay gives us the proportion of land area of each region that is in each of soil stress categories.
} 
difference not accounted for by the included characteristics will be reflected in the country dummy coefficients.

Finally, economic theory places few if any restrictions on the functional form of the hedonic price function. In this study, we adopt a generalized linear form, where the dependent variable and each of the continuous independent variables is represented by the Box-Cox transformation. This is a mathematical expression that assumes a different functional form depending on the transformation parameter, and which can assume both linear and logarithmic forms, as well as intermediate nonlinear functional forms.

Thus the general functional form of our model is given by

$W_{L}\left(\lambda_{0}\right)=\sum_{n} \alpha_{n} X_{n}\left(\lambda_{n}\right)+\sum_{d} \gamma_{d} D_{d}+\varepsilon$,

where $W_{L}\left(\lambda_{0}\right)$ is the Box-Cox transformation of the dependent price variable, $W_{L}>0$; that is,

$W_{L}\left(\lambda_{0}\right)= \begin{cases}\frac{W_{L}^{\lambda_{0}}-1}{\lambda_{0}}, & \lambda_{0} \neq 0, \\ \ln W_{L}, & \lambda_{0}=0 .\end{cases}$

Similarly, $X_{n}\left(\lambda_{n}\right)$ is the Box-Cox transformation of the continuous quality variable $X_{n}$ where $X_{n}\left(\lambda_{n}\right)=\left(X_{n}^{\lambda_{n}}-1\right) / \lambda_{n}$ if $\lambda_{n} \neq 0$ and $X_{n}\left(\lambda_{n}\right)=\ln X_{n}$ if $\lambda_{n}=0$. Variables represented by $D$ are country dummy variables, not subject to transformation; $\lambda, \alpha$, and $\gamma$ are unknown parameter vectors, and $\varepsilon$ is a stochastic disturbance.

\subsection{Labor input}

Data on labor input in agriculture consist of hours worked disaggregated by hired and self-employed and unpaid family workers (Eurostat, 2000). Compensation of hired farm workers is defined as the average hourly wage plus the value of perquisites and employer contributions to social insurance.

The compensation of self-employed workers is not directly observable. These data are derived using the accounting identity where the value of total product is equal to total factor outlay.

\section{Relative prices}

We estimate purchasing power parities for agricultural output in 1996 for the 11 European countries and the United States using Eq. (10) above. Equation (12) yields purchasing power parities for capital, land, labor, and materials inputs. These are relative prices expressed in terms of national currencies per dollar. We translate the purchasing power parities into relative prices in dollars by dividing by the exchange rate. These relative prices are shown in Table 1.

According to Table 1, the levels of output prices in the 11 European countries in 1996 were well above the U.S. price level. The relative price of output was highest in Sweden at 1.629 , or some $60 \%$ above the U.S. price. The Netherlands had the lowest output price relative to the United States in 1996 at 1.338 .

The European countries also faced higher prices for intermediate inputs in 1996. Relative prices ranged from 1.35 in Denmark to 1.055 in Ireland. The cost of capital input, other than land, exceeded that in the United States in all of the European countries except Germany, Ireland, and Italy. Among the 11 European countries, only Sweden had a lower price of land input in 1996. By contrast, the purchasing power parities for labor input in 1996 represent substantially lower costs of labor input in the European countries relative to the United States. In 1996, hourly earnings in the 11 European countries averaged slightly more than $50 \%$ of U.S. hourly earnings. This result is consistent with the observation by Ball et al. (2001) that agriculture in the European countries is relatively labor intensive.

We have estimated purchasing power parities between the 11 European currencies and the dollar in 1996. We have also compiled price indexes for output and inputs in each country for the period 1973-2002. We obtain indexes of output and input prices in each country relative to those in the United States for each year by linking these time-series price indexes with estimates of relative prices for the base period. Table 2 presents indexes of relative output prices in the 11 European countries and the United States for the period 1973-2002, with a base equal to one in the United States in 1996.

According to the results presented in Table 2, the price index of agricultural output in Ireland in 1973 was 0.574 , while that in the United States was 0.637. This implies that the Irish aggregate output price index in 1973 was only $90 \%$ of that in the United States. In that same year, the ratio of the output price index in the United Kingdom to the U.S. price index was 95\%. These results imply that Ireland and the United Kingdom had a competitive advantage relative to the United States in 1973.

Table 1

Output and input prices relative to the United States, 1996

\begin{tabular}{lccccccccccc}
\hline & Belgium & Denmark & Germany & Greece & Spain & France & Ireland & Italy & Netherlands & Sweden & $\begin{array}{l}\text { United } \\
\text { Kingdom }\end{array}$ \\
\hline Output & 1.3551 & 1.4402 & 1.4711 & 1.5046 & 1.3520 & 1.4907 & 1.4273 & 1.4973 & 1.3381 & 1.6300 & 1.6020 \\
Materials & 1.1623 & 1.3498 & 1.3087 & 1.1894 & 1.1886 & 1.2846 & 1.0550 & 1.3448 & 1.2356 & 1.3475 & 1.1729 \\
Capital & 1.2399 & 1.5483 & 0.8577 & 1.0143 & 1.1585 & 1.2051 & 0.8242 & 0.8577 & 1.5246 & 1.1211 & 1.2432 \\
Land & 3.2487 & 1.0169 & 2.2333 & 4.9054 & 4.6744 & 1.9533 & 4.1060 & 2.9146 & 8.1226 & 0.5692 & 2.2617 \\
Labor & 0.7923 & 0.8452 & 0.5308 & 0.3235 & 0.4221 & 0.5601 & 0.2896 & 0.4217 & 0.7048 & 0.4701 & 0.3971 \\
\hline
\end{tabular}


Table 2

Output price relative to the 1996 level for the United States

\begin{tabular}{|c|c|c|c|c|c|c|c|c|c|c|c|c|}
\hline Year & Belgium & Denmark & Germany & Greece & Spain & France & Ireland & Italy & Netherlands & Sweden & $\begin{array}{l}\text { United } \\
\text { Kingdom }\end{array}$ & $\begin{array}{l}\text { United } \\
\text { States }\end{array}$ \\
\hline 1973 & 0.7189 & 0.8414 & 0.8690 & 0.8749 & 0.7579 & 0.7493 & 0.5742 & 0.7218 & 0.7702 & 1.3616 & 0.6032 & 0.6373 \\
\hline 1974 & 0.6849 & 0.7823 & 0.8499 & 0.8619 & 0.7454 & 0.7638 & 0.5920 & 0.7182 & 0.6830 & 1.1678 & 0.6449 & 0.7159 \\
\hline 1975 & 0.8470 & 0.9294 & 1.0029 & 0.9108 & 0.7809 & 0.9432 & 0.7229 & 0.7992 & 0.7789 & 1.3487 & 0.7414 & 0.6720 \\
\hline 1976 & 0.9550 & 0.9645 & 1.0532 & 0.8432 & 0.7470 & 0.9159 & 0.7220 & 0.7519 & 0.8381 & 1.3768 & 0.7594 & 0.6790 \\
\hline 1977 & 0.9108 & 0.9524 & 1.0751 & 0.8848 & 0.8051 & 0.9080 & 0.8317 & 0.8665 & 0.9061 & 1.4044 & 0.7834 & 0.6612 \\
\hline 1978 & 1.0226 & 1.1408 & 1.1852 & 0.9902 & 0.8892 & 1.0236 & 1.0159 & 0.9874 & 0.9657 & 1.4626 & 0.8645 & 0.7418 \\
\hline 1979 & 1.1408 & 1.2120 & 1.3361 & 1.1751 & 1.0657 & 1.1384 & 1.1499 & 1.1418 & 1.0751 & 1.5833 & 1.0603 & 0.8220 \\
\hline 1980 & 1.2443 & 1.2635 & 1.3525 & 1.2180 & 1.0405 & 1.2306 & 1.1435 & 1.2313 & 1.0960 & 1.7706 & 1.2525 & 0.8629 \\
\hline 1981 & 1.0567 & 1.1106 & 1.1422 & 1.1143 & 0.9446 & 1.0741 & 1.0503 & 1.0524 & 0.9942 & 1.6078 & 1.2041 & 0.8828 \\
\hline 1982 & 0.9471 & 1.0255 & 1.0720 & 1.1078 & 0.8990 & 0.9877 & 0.9912 & 1.0124 & 0.9255 & 1.3877 & 1.1172 & 0.8589 \\
\hline 1983 & 0.9305 & 1.0077 & 1.0159 & 1.0179 & 0.7462 & 0.9282 & 0.9440 & 0.9645 & 0.8926 & 1.2011 & 1.0228 & 0.9684 \\
\hline 1984 & 0.8343 & 0.8826 & 0.8990 & 0.9505 & 0.7236 & 0.8241 & 0.8360 & 0.8984 & 0.8244 & 1.1364 & 0.9002 & 0.9236 \\
\hline 1985 & 0.8083 & 0.8434 & 0.8508 & 0.9226 & 0.6893 & 0.8173 & 0.8104 & 0.8659 & 0.7742 & 1.0898 & 0.8569 & 0.8416 \\
\hline 1986 & 0.9995 & 1.0873 & 1.0911 & 1.0122 & 0.9700 & 1.0618 & 1.0391 & 1.1093 & 0.9850 & 1.3683 & 0.9908 & 0.8338 \\
\hline 1987 & 1.1779 & 1.2426 & 1.2683 & 1.1486 & 1.0594 & 1.1975 & 1.2007 & 1.2818 & 1.1576 & 1.6381 & 1.1380 & 0.8458 \\
\hline 1988 & 1.1893 & 1.2409 & 1.2943 & 1.2242 & 1.1314 & 1.2225 & 1.3346 & 1.3319 & 1.1696 & 1.7758 & 1.2602 & 0.9174 \\
\hline 1989 & 1.2298 & 1.2062 & 1.2890 & 1.2039 & 1.2147 & 1.2347 & 1.3560 & 1.3491 & 1.1497 & 1.7435 & 1.2372 & 0.9432 \\
\hline 1990 & 1.3653 & 1.3490 & 1.4065 & 1.5071 & 1.3944 & 1.4426 & 1.3259 & 1.6194 & 1.2828 & 1.9501 & 1.3796 & 0.9505 \\
\hline 1991 & 1.2883 & 1.2880 & 1.3487 & 1.5173 & 1.4009 & 1.3694 & 1.2575 & 1.6000 & 1.2604 & 1.9202 & 1.3832 & 0.9158 \\
\hline 1992 & 1.3016 & 1.3680 & 1.4151 & 1.4773 & 1.3376 & 1.3870 & 1.3570 & 1.6014 & 1.3069 & 1.9932 & 1.4226 & 0.9025 \\
\hline 1993 & 1.1619 & 1.1900 & 1.3151 & 1.2884 & 1.1778 & 1.2860 & 1.2654 & 1.2815 & 1.1539 & 1.4620 & 1.3541 & 0.9359 \\
\hline 1994 & 1.2436 & 1.2474 & 1.3681 & 1.3371 & 1.2698 & 1.3678 & 1.3055 & 1.2842 & 1.2084 & 1.5008 & 1.4115 & 0.9143 \\
\hline 1995 & 1.3525 & 1.4619 & 1.5540 & 1.5204 & 1.5182 & 1.5526 & 1.4647 & 1.3659 & 1.3789 & 1.5905 & 1.5900 & 0.9456 \\
\hline 1996 & 1.3551 & 1.4402 & 1.4711 & 1.5046 & 1.3520 & 1.4907 & 1.4273 & 1.4973 & 1.3381 & 1.6300 & 1.6020 & 1.0000 \\
\hline 1997 & 1.1990 & 1.2572 & 1.2808 & 1.3574 & 1.1549 & 1.3154 & 1.3066 & 1.3619 & 1.1790 & 1.4150 & 1.4870 & 0.9635 \\
\hline 1998 & 1.1010 & 1.1035 & 1.1886 & 1.2530 & 1.1282 & 1.2871 & 1.2223 & 1.3171 & 1.1277 & 1.3959 & 1.3762 & 0.9196 \\
\hline 1999 & 0.9919 & 1.0398 & 1.0679 & 1.2069 & 1.1245 & 1.1894 & 1.1436 & 1.2168 & 1.0219 & 1.2833 & 1.2892 & 0.8856 \\
\hline 2000 & 0.9161 & 0.9693 & 0.9910 & 1.0503 & 0.9578 & 1.0508 & 1.0393 & 1.0735 & 0.9268 & 1.1717 & 1.1778 & 0.8966 \\
\hline 2001 & 0.9698 & 1.0146 & 0.9935 & 1.0594 & 0.9665 & 1.0759 & 1.0173 & 1.0877 & 0.9664 & 1.1038 & 1.2060 & 0.9053 \\
\hline 2002 & 0.9459 & 0.9784 & 1.0061 & 1.1319 & 0.9924 & 1.0945 & 1.0406 & 1.1689 & 1.0126 & 1.1560 & 1.2141 & 0.8733 \\
\hline
\end{tabular}

Output prices in the other countries in the comparison were well above the level in the United States. The price index in Belgium in 1973 was 0.719 . This was nearly $13 \%$ above the U.S. price index. In France, the index of output prices was 0.749 , or $18 \%$ above the United States level. The price gap widens further when the comparison is between Sweden and the United States. The index of output prices in Sweden in 1973 was 1.362 , or more than double the U.S. price index.

The levels of output prices in the 11 European countries increased relative to the United States during the 1970s. This was a consequence of more rapid inflation in most European countries and an appreciation of the European currencies relative to the dollar through 1980. The competitiveness of U.S. agriculture reached a temporary peak in that year.

The situation changed in the early 1980s. By then the European countries and the United States were vigorously pursuing policies to combat inflation. The change to restrictive monetary policy initiated by the Federal Reserve pushed up interest rates sharply. The dollar appreciated on foreign exchange markets, and world export prices started to fall. By 1984 the price level in most European countries was well below the U.S. price. ${ }^{19}$

\footnotetext{
${ }^{19}$ Prices in the United States remained at or near-record levels long after the momentum of inflation was broken in the early 1980s. A possible explanation
}

This had the short-run effect of restoring the competitiveness of European Union agriculture. ${ }^{20}$

The U.S. inflation rate slowed between 1981 and 1986. This was followed by a rapid depreciation of the dollar. By 1986 the level of prices in the European countries, denominated in dollars, once again exceeded the U.S. price. The continued weakness of the dollar through the early 1990s resulted in a further deterioration of the international competitiveness of European Union agriculture. By 1995 prices in most European countries were at their highest levels relative to the United States. But a strengthening dollar between 1996 and 2001 eroded much of the competitive advantage of the United States. ${ }^{21}$

for this can be found in the Agricultural and Food Act of 1981. In the 1981 act, the tie between target prices and rates of inflation was broken, and specific levels of price support were mandated for each year between 1982 and 1985 on the assumption that high rates of inflation would continue.

${ }^{20}$ Furthermore, the European Union, under its Common Agricultural Policy (CAP), embarked on a program of subsidized grain sales to increase its market share of world exports. This came largely at the expense of the United States.

${ }^{21}$ Another factor contributing to the decline in relative prices in the European countries was a series of reforms of the CAP that culminated in the MacSharry reforms of 1992. Those reforms focused on major commodities by lowering guaranteed prices and compensating farmers for lower prices with direct payments. Guaranteed prices were further reduced under Agenda 2000. 
Table 3

Materials price relative to the 1996 level for the United States

\begin{tabular}{|c|c|c|c|c|c|c|c|c|c|c|c|c|}
\hline Year & Belgium & Denmark & Germany & Greece & Spain & France & Ireland & Italy & Netherlands & Sweden & $\begin{array}{l}\text { United } \\
\text { Kingdom }\end{array}$ & $\begin{array}{l}\text { United } \\
\text { States }\end{array}$ \\
\hline 1973 & 0.7097 & 0.6968 & 0.7468 & 0.7168 & 0.3821 & 0.6495 & 0.4187 & 0.7122 & 0.6033 & 0.6904 & 0.4491 & 0.4339 \\
\hline 1974 & 0.6591 & 0.7687 & 0.7665 & 0.6856 & 0.4237 & 0.6449 & 0.4622 & 0.7191 & 0.5808 & 0.6047 & 0.5590 & 0.5420 \\
\hline 1975 & 0.7225 & 0.8348 & 0.7996 & 0.6532 & 0.4608 & 0.8047 & 0.5198 & 0.8217 & 0.6284 & 0.6417 & 0.6040 & 0.5546 \\
\hline 1976 & 0.7681 & 0.8504 & 0.8595 & 0.5810 & 0.4476 & 0.7337 & 0.5102 & 0.7651 & 0.6481 & 0.6666 & 0.5731 & 0.5605 \\
\hline 1977 & 0.8385 & 0.9106 & 0.9616 & 0.5633 & 0.4845 & 0.6921 & 0.5964 & 0.8139 & 0.7213 & 0.7021 & 0.6324 & 0.5697 \\
\hline 1978 & 0.9161 & 0.9724 & 1.0237 & 0.5945 & 0.5869 & 0.7738 & 0.6832 & 0.9032 & 0.8024 & 0.7606 & 0.7163 & 0.5773 \\
\hline 1979 & 1.0347 & 1.0737 & 1.1687 & 0.7455 & 0.7035 & 0.8757 & 0.7697 & 1.0162 & 0.9112 & 0.8620 & 0.8832 & 0.6459 \\
\hline 1980 & 1.1387 & 1.1530 & 1.2125 & 0.8357 & 0.7897 & 0.9836 & 0.8641 & 1.3044 & 0.9735 & 1.0110 & 1.0931 & 0.7202 \\
\hline 1981 & 0.9678 & 1.0565 & 1.0657 & 0.7797 & 0.7341 & 0.8682 & 0.7675 & 1.1205 & 0.8405 & 0.9595 & 1.0376 & 0.7747 \\
\hline 1982 & 0.8648 & 0.9949 & 1.0066 & 0.7459 & 0.6998 & 0.8188 & 0.7434 & 1.0531 & 0.8197 & 0.8694 & 0.9502 & 0.7716 \\
\hline 1983 & 0.8375 & 0.9696 & 0.9756 & 0.6965 & 0.7247 & 0.7783 & 0.7005 & 1.0369 & 0.7831 & 0.7839 & 0.8882 & 0.8193 \\
\hline 1984 & 0.8006 & 0.9005 & 0.8829 & 0.6487 & 0.7215 & 0.7193 & 0.6557 & 0.9597 & 0.7375 & 0.7798 & 0.8031 & 0.8024 \\
\hline 1985 & 0.7658 & 0.8404 & 0.8075 & 0.6289 & 0.7143 & 0.7188 & 0.6512 & 0.8972 & 0.6936 & 0.7930 & 0.7723 & 0.7444 \\
\hline 1986 & 0.9203 & 1.0461 & 1.0043 & 0.7060 & 0.9489 & 0.9169 & 0.7928 & 1.0959 & 0.8532 & 0.9657 & 0.8580 & 0.6868 \\
\hline 1987 & 1.0539 & 1.1800 & 1.1297 & 0.8123 & 1.1190 & 1.0338 & 0.8545 & 1.2567 & 0.9654 & 1.0967 & 0.9561 & 0.6858 \\
\hline 1988 & 1.0563 & 1.2483 & 1.1613 & 0.8789 & 1.1703 & 1.0637 & 0.9009 & 1.2457 & 0.9920 & 1.2012 & 1.0390 & 0.8014 \\
\hline 1989 & 1.0189 & 1.1764 & 1.1086 & 0.8373 & 1.1203 & 1.0341 & 0.8590 & 1.2168 & 0.9434 & 1.2369 & 1.0175 & 0.8387 \\
\hline 1990 & 1.1945 & 1.2899 & 1.2413 & 1.0275 & 1.3025 & 1.1948 & 1.0041 & 1.4141 & 1.0720 & 1.4044 & 1.1439 & 0.8266 \\
\hline 1991 & 1.0957 & 1.2521 & 1.2148 & 1.0650 & 1.2986 & 1.1471 & 0.9741 & 1.4297 & 1.0669 & 1.4020 & 1.1569 & 0.8247 \\
\hline 1992 & 1.1948 & 1.3232 & 1.3047 & 1.1512 & 1.3232 & 1.1951 & 1.0481 & 1.4349 & 1.1457 & 1.4817 & 1.1598 & 0.8223 \\
\hline 1993 & 1.0550 & 1.2194 & 1.1762 & 1.0158 & 1.0663 & 1.0914 & 0.9106 & 1.1811 & 1.0781 & 1.0961 & 1.0220 & 0.8520 \\
\hline 1994 & 1.0407 & 1.2166 & 1.2062 & 1.0790 & 1.0774 & 1.1193 & 0.9378 & 1.1448 & 1.1063 & 1.0975 & 1.0438 & 0.8719 \\
\hline 1995 & 1.1512 & 1.3693 & 1.3715 & 1.1614 & 1.1721 & 1.2799 & 1.0217 & 1.2211 & 1.2621 & 1.2180 & 1.1261 & 0.9092 \\
\hline 1996 & 1.1623 & 1.3498 & 1.3087 & 1.1894 & 1.1886 & 1.2846 & 1.0550 & 1.3448 & 1.2356 & 1.3475 & 1.1729 & 1.0000 \\
\hline 1997 & 1.0119 & 1.1987 & 1.1492 & 1.0672 & 1.0524 & 1.1285 & 0.9926 & 1.2104 & 1.0782 & 1.1925 & 1.1666 & 0.9726 \\
\hline 1998 & 0.9561 & 1.1574 & 1.0619 & 0.9870 & 1.0462 & 1.0797 & 0.9170 & 1.1632 & 1.0536 & 1.1466 & 1.1160 & 0.9120 \\
\hline 1999 & 0.9000 & 1.0997 & 0.9975 & 0.9681 & 0.9539 & 1.0191 & 0.8777 & 1.1263 & 1.0030 & 1.1078 & 1.0782 & 0.8685 \\
\hline 2000 & 0.8286 & 0.9652 & 0.8824 & 0.8736 & 0.8413 & 0.9033 & 0.8011 & 1.0084 & 0.9009 & 1.0205 & 1.0338 & 0.9054 \\
\hline 2001 & 0.8288 & 0.9869 & 0.8117 & 0.8463 & 0.8435 & 0.9190 & 0.8141 & 1.0309 & 0.9329 & 0.9595 & 1.0154 & 0.9501 \\
\hline 2002 & 0.8839 & 1.0452 & 0.9106 & 0.9029 & 0.9963 & 0.9687 & 0.8788 & 1.0874 & 1.0030 & 1.0268 & 1.0574 & 0.9578 \\
\hline
\end{tabular}

According to the results reported in Table 3, the price of materials in the European countries in 1973 exceeded that in the United States. These relative prices trend higher during the 1970s, but the rapid appreciation of the dollar in the early 1980s reversed this trend. By 1984 the price of materials input in the European countries had fallen below the level in the United States. The price of materials increased relative to the United States after 1984, a consequence of the depreciation of the dollar. Relative materials prices reached a peak in the early 1990s. But the subsequent appreciation of the dollar resulted in a decline in relative prices. By 2001 the relative cost of materials in most European countries was again below that in the United States.

A comparison of capital input prices is provided in Table 4 . The patterns of change for relative capital input prices are similar to those for relative output and materials input prices. Initially, the cost of capital in a number of the European countries was below that in the United States but rose to well above the United States level by 1979. The rapid increase in the cost of capital in the United States during the early 1980s and the appreciation of the dollar resulted in a decline in this relative price. By 1984 the price of capital in the European countries had fallen to its lowest level relative to the United States. The subsequent weakness of the dollar and declining capital costs in the United States resulted in an increase in the cost of capital in the European countries relative to the United States. The appreciation of the dollar after 1995 reversed this trend.

As can be seen in Table 5, the differences in relative land input prices in 1973 were much larger than differences in relative capital input prices. The price of land input in the Netherlands in 1973 was more than six times the level of prices in the United States. In Sweden, however, this relative price was less than one-half the U.S. price. The differences in relative prices had narrowed substantially by the early 1980s, a result of rapid increases in the price of land input in the United States and the appreciation of the dollar. But the farm debt crisis of the 1980s and the ensuing collapse of land prices in the United States resulted in a sharp divergence of relative prices. By 1992 the price of land input in the Netherlands was 12 times the U.S. price. The recovery of land prices in the United States during mid 1990s and the appreciation of the dollar resulted in some narrowing of the differences in relative land input prices, but price levels in most European countries remained well above the level in the United States.

Finally, a comparison of labor input prices appears in Table 6 . The patterns of change in relative wage rates bear little resemblance to those for relative materials and capital 
Table 4

Capital price relative to the 1996 level for the United States

\begin{tabular}{|c|c|c|c|c|c|c|c|c|c|c|c|c|}
\hline Year & Belgium & Denmark & Germany & Greece & Spain & France & Ireland & Italy & Netherlands & Sweden & $\begin{array}{l}\text { United } \\
\text { Kingdom }\end{array}$ & $\begin{array}{l}\text { United } \\
\text { States }\end{array}$ \\
\hline 1973 & 0.3716 & 0.2517 & 0.2113 & 0.1734 & 0.1982 & 0.2447 & 0.1597 & 0.2827 & 0.3003 & 0.3556 & 0.3145 & 0.2737 \\
\hline 1974 & 0.4216 & 0.3428 & 0.2414 & 0.1998 & 0.2322 & 0.2869 & 0.1948 & 0.3501 & 0.3515 & 0.3986 & 0.3811 & 0.2942 \\
\hline 1975 & 0.4362 & 0.3240 & 0.2671 & 0.2091 & 0.2581 & 0.3448 & 0.2109 & 0.3423 & 0.3798 & 0.4784 & 0.4314 & 0.3225 \\
\hline 1976 & 0.4415 & 0.3397 & 0.2611 & 0.2111 & 0.2440 & 0.3270 & 0.2044 & 0.3221 & 0.3891 & 0.4927 & 0.4213 & 0.3402 \\
\hline 1977 & 0.5138 & 0.3899 & 0.2878 & 0.2349 & 0.2546 & 0.3616 & 0.2357 & 0.3840 & 0.4734 & 0.5090 & 0.4654 & 0.3752 \\
\hline 1978 & 0.6248 & 0.5253 & 0.3477 & 0.2753 & 0.2987 & 0.4454 & 0.2897 & 0.4960 & 0.5801 & 0.5361 & 0.5582 & 0.4217 \\
\hline 1979 & 0.7146 & 0.6116 & 0.4450 & 0.3268 & 0.4057 & 0.5024 & 0.3118 & 0.6781 & 0.6922 & 0.6096 & 0.7171 & 0.4850 \\
\hline 1980 & 0.8420 & 0.6444 & 0.4721 & 0.3738 & 0.4585 & 0.5748 & 0.3545 & 0.3783 & 0.8165 & 0.7717 & 0.8645 & 0.5739 \\
\hline 1981 & 0.8121 & 0.5912 & 0.4453 & 0.4091 & 0.4683 & 0.5853 & 0.3443 & 0.3674 & 0.7898 & 0.7476 & 0.8610 & 0.7229 \\
\hline 1982 & 0.6985 & 0.6171 & 0.4206 & 0.4323 & 0.4839 & 0.6160 & 0.3342 & 0.3529 & 0.7296 & 0.6687 & 0.8175 & 0.7490 \\
\hline 1983 & 0.6174 & 0.5495 & 0.3922 & 0.3926 & 0.4252 & 0.5551 & 0.3465 & 0.3527 & 0.6011 & 0.6123 & 0.7677 & 0.8189 \\
\hline 1984 & 0.5699 & 0.4527 & 0.3643 & 0.3363 & 0.4650 & 0.4345 & 0.3291 & 0.3270 & 0.5224 & 0.5774 & 0.7269 & 0.9273 \\
\hline 1985 & 0.5502 & 0.4427 & 0.3520 & 0.3035 & 0.4139 & 0.4478 & 0.3910 & 0.3217 & 0.5055 & 0.6113 & 0.7024 & 0.8568 \\
\hline 1986 & 0.6818 & 0.6066 & 0.4698 & 0.3815 & 0.5722 & 0.6120 & 0.5160 & 0.4427 & 0.6639 & 0.7607 & 0.6864 & 0.7532 \\
\hline 1987 & 0.7887 & 0.8423 & 0.5752 & 0.4302 & 0.6953 & 0.7245 & 0.6126 & 0.5524 & 0.8758 & 0.9020 & 0.8636 & 0.8016 \\
\hline 1988 & 0.8574 & 0.9869 & 0.6159 & 0.5179 & 0.9160 & 0.8377 & 0.7574 & 0.6033 & 0.9938 & 1.0233 & 1.0550 & 0.8373 \\
\hline 1989 & 0.8779 & 0.9338 & 0.6315 & 0.5855 & 1.0154 & 0.8571 & 0.6956 & 0.6349 & 1.0555 & 1.0330 & 1.0165 & 0.8531 \\
\hline 1990 & 1.0603 & 1.2977 & 0.8195 & 0.7719 & 1.3405 & 1.1254 & 0.7369 & 0.7986 & 1.4497 & 1.2844 & 1.1575 & 0.8790 \\
\hline 1991 & 1.1189 & 1.3335 & 0.7651 & 0.9180 & 1.4161 & 1.1168 & 0.7082 & 0.8912 & 1.4772 & 1.2882 & 1.1558 & 0.8662 \\
\hline 1992 & 1.1981 & 1.3562 & 0.8495 & 0.9803 & 1.3493 & 1.1972 & 0.7972 & 0.8977 & 1.5405 & 1.2877 & 1.2976 & 0.8575 \\
\hline 1993 & 1.0386 & 1.1536 & 0.7311 & 0.9631 & 0.9621 & 0.9988 & 0.6791 & 0.7191 & 1.3364 & 0.9620 & 1.2480 & 0.8659 \\
\hline 1994 & 1.0875 & 1.2803 & 0.7776 & 0.9179 & 0.9503 & 1.1042 & 0.6326 & 0.7326 & 1.4340 & 0.9413 & 1.3018 & 0.9303 \\
\hline 1995 & 1.3093 & 1.6696 & 0.9796 & 1.0049 & 1.1815 & 1.2772 & 0.9090 & 0.7821 & 1.6589 & 1.1103 & 1.3563 & 0.9795 \\
\hline 1996 & 1.2399 & 1.5483 & 0.8577 & 1.0143 & 1.1585 & 1.2051 & 0.8242 & 0.8577 & 1.5246 & 1.1211 & 1.2432 & 1.0000 \\
\hline 1997 & 1.0855 & 1.2046 & 0.7172 & 0.8291 & 0.9516 & 1.0283 & 0.7563 & 0.7877 & 1.3631 & 0.9471 & 1.1899 & 1.0295 \\
\hline 1998 & 1.0289 & 1.0290 & 0.7018 & 0.8810 & 0.9498 & 0.9730 & 0.6125 & 0.7646 & 1.2836 & 0.8922 & 1.1543 & 0.9902 \\
\hline 1999 & 0.9809 & 1.0658 & 0.6775 & 0.8359 & 0.8955 & 0.9534 & 0.5603 & 0.7603 & 1.2689 & 0.8702 & 1.0714 & 1.0669 \\
\hline 2000 & 0.9091 & 1.0311 & 0.6481 & 0.6449 & 0.8111 & 0.8796 & 0.5424 & 0.6555 & 1.1911 & 0.7709 & 1.0067 & 1.0908 \\
\hline 2001 & 0.8786 & 0.9727 & 0.6552 & 0.6860 & 0.7461 & 0.8551 & 0.5512 & 0.6624 & 1.1471 & 0.7055 & 0.9380 & 1.0165 \\
\hline 2002 & 0.9138 & 0.9849 & 0.6611 & 0.7411 & 0.7726 & 0.8467 & 0.5572 & 0.6867 & 1.1616 & 0.8341 & 0.9811 & 0.9994 \\
\hline
\end{tabular}

Table 5

Land price relative to the 1996 level for the United States

\begin{tabular}{|c|c|c|c|c|c|c|c|c|c|c|c|c|}
\hline Year & Belgium & Denmark & Germany & Greece & Spain & France & Ireland & Italy & Netherlands & Sweden & $\begin{array}{l}\text { United } \\
\text { Kingdom }\end{array}$ & $\begin{array}{l}\text { United } \\
\text { States }\end{array}$ \\
\hline 1973 & 0.7476 & 0.1406 & 0.7791 & 1.6116 & 1.0369 & 0.5136 & 0.2370 & 0.3005 & 1.7234 & 0.1077 & 0.3327 & 0.2628 \\
\hline 1974 & 0.7331 & 0.2983 & 0.8246 & 1.5700 & 0.9639 & 0.7068 & 0.5083 & 0.4767 & 2.6926 & 0.1038 & 0.2439 & 0.2347 \\
\hline 1975 & 0.4299 & 0.1669 & 0.6506 & 1.0085 & 0.7287 & 0.7322 & 0.3427 & 0.2964 & 1.3595 & 0.1309 & 0.0993 & 0.1870 \\
\hline 1976 & 0.5564 & 0.2614 & 0.3995 & 0.7937 & 0.5020 & 0.4886 & 0.4899 & 0.2375 & 0.9472 & 0.1038 & 0.0913 & 0.1786 \\
\hline 1977 & 0.9868 & 0.4459 & 0.3768 & 0.7386 & 0.3953 & 0.3653 & 0.7561 & 0.2180 & 1.9883 & 0.0691 & 0.0897 & 0.2574 \\
\hline 1978 & 1.8310 & 0.9723 & 0.5799 & 0.7027 & 0.3490 & 0.3403 & 0.7729 & 0.2706 & 3.1814 & 0.0433 & 0.1312 & 0.3954 \\
\hline 1979 & 2.3771 & 1.1048 & 1.8706 & 0.8153 & 0.3919 & 0.3143 & 0.8262 & 0.4633 & 4.0613 & 0.0383 & 0.3463 & 0.5880 \\
\hline 1980 & 4.2142 & 0.8900 & 2.3255 & 1.1903 & 0.5018 & 0.4865 & 0.5640 & 0.6403 & 3.9482 & 0.0875 & 0.4108 & 0.8714 \\
\hline 1981 & 4.4137 & 0.3562 & 3.6310 & 2.2548 & 0.6498 & 1.0723 & 0.7781 & 1.1652 & 3.0703 & 0.1548 & 0.3782 & 1.4552 \\
\hline 1982 & 2.8306 & 0.2170 & 2.9133 & 3.3564 & 0.8629 & 1.2170 & 0.5838 & 0.8287 & 2.3024 & 0.1694 & 0.5438 & 1.3201 \\
\hline 1983 & 2.0442 & 0.2456 & 2.5110 & 3.0519 & 0.7694 & 0.8464 & 0.9452 & 0.7133 & 2.0477 & 0.1612 & 0.5734 & 1.5105 \\
\hline 1984 & 2.0379 & 0.1634 & 2.5738 & 2.2900 & 1.0894 & 0.5391 & 0.7308 & 0.5458 & 2.4152 & 0.1629 & 0.6335 & 1.8294 \\
\hline 1985 & 1.9121 & 0.2619 & 2.2268 & 1.6729 & 0.8711 & 0.5251 & 1.3317 & 0.4500 & 2.9347 & 0.2295 & 0.4965 & 1.3250 \\
\hline 1986 & 2.0398 & 0.3803 & 2.5510 & 1.3360 & 1.8781 & 0.8163 & 1.9531 & 0.7226 & 5.4748 & 0.2913 & 0.6897 & 0.7463 \\
\hline 1987 & 2.3424 & 0.6753 & 3.0895 & 1.7515 & 3.0838 & 1.4638 & 2.1547 & 1.2559 & 6.6694 & 0.4063 & 0.9191 & 0.8502 \\
\hline 1988 & 3.0165 & 0.9391 & 3.2448 & 2.1800 & 6.1029 & 1.9889 & 2.9627 & 1.8939 & 9.5227 & 0.5723 & 1.4137 & 0.8892 \\
\hline 1989 & 3.7179 & 0.8978 & 3.7953 & 3.1121 & 7.5286 & 1.9941 & 3.3163 & 2.5015 & 9.7868 & 0.7143 & 1.5104 & 0.8417 \\
\hline 1990 & 4.3123 & 1.4749 & 5.7303 & 4.5986 & 9.1538 & 2.9397 & 3.5645 & 3.3281 & 10.4906 & 1.1580 & 1.5540 & 0.8944 \\
\hline 1991 & 4.5418 & 1.4058 & 4.1079 & 4.7887 & 7.5596 & 2.6846 & 2.8606 & 4.3389 & 9.3810 & 1.1142 & 1.1647 & 0.8102 \\
\hline 1992 & 4.5395 & 0.9871 & 3.7840 & 6.3217 & 5.3179 & 2.5337 & 2.9251 & 3.4712 & 9.0047 & 0.8318 & 0.9174 & 0.7335 \\
\hline 1993 & 2.7524 & 0.5184 & 1.8923 & 5.2007 & 3.2569 & 1.7596 & 2.1784 & 2.4442 & 6.6270 & 0.3426 & 1.1274 & 0.7166 \\
\hline
\end{tabular}




\begin{tabular}{|c|c|c|c|c|c|c|c|c|c|c|c|c|}
\hline Year & Belgium & Denmark & Germany & Greece & Spain & France & Ireland & Italy & Netherlands & Sweden & $\begin{array}{l}\text { United } \\
\text { Kingdom }\end{array}$ & $\begin{array}{l}\text { United } \\
\text { States }\end{array}$ \\
\hline 1994 & 2.6834 & 0.7136 & 2.2536 & 5.7715 & 3.3266 & 1.9139 & 1.6486 & 2.6045 & 5.7365 & 0.4976 & 1.3942 & 0.8802 \\
\hline 1995 & 3.8427 & 1.2129 & 3.9673 & 6.0218 & 4.7560 & 2.3241 & 4.4059 & 3.0330 & 8.8239 & 0.6479 & 2.2077 & 0.9605 \\
\hline 1996 & 3.2487 & 1.0169 & 2.2333 & 4.9054 & 4.6744 & 1.9533 & 4.1060 & 2.9146 & 8.1226 & 0.5692 & 2.2617 & 1.0000 \\
\hline 1997 & 2.6307 & 0.6778 & 1.7461 & 4.1281 & 4.4010 & 1.4864 & 4.4092 & 2.3513 & 7.6223 & 0.4543 & 1.5207 & 1.0979 \\
\hline 1998 & 2.1162 & 0.4125 & 1.5562 & 3.4279 & 4.7489 & 1.2974 & 2.6765 & 2.2096 & 8.0486 & 0.4867 & 1.2129 & 0.9085 \\
\hline 1999 & 2.0724 & 0.6391 & 1.4925 & 4.5035 & 4.7363 & 1.3400 & 2.2223 & 2.4576 & 5.4840 & 0.5377 & 0.9530 & 1.1808 \\
\hline 2000 & 2.4700 & 0.7612 & 1.8154 & 3.3819 & 3.5680 & 1.4991 & 3.6493 & 1.9878 & 4.8812 & 0.4952 & 1.0887 & 1.2241 \\
\hline 2001 & 2.2189 & 0.8439 & 1.9399 & 2.3662 & 2.7856 & 1.4077 & 4.1153 & 2.2206 & 4.4436 & 0.5818 & 0.8530 & 0.8209 \\
\hline 2002 & 2.0984 & 0.7877 & 1.6661 & 2.4435 & 2.4160 & 1.2550 & 2.2444 & 2.0184 & 4.9510 & 0.7267 & 0.7602 & 0.6918 \\
\hline
\end{tabular}

Table 6

Labor price relative to the 1996 level for the United States

\begin{tabular}{|c|c|c|c|c|c|c|c|c|c|c|c|c|}
\hline Year & Belgium & Denmark & Germany & Greece & Spain & France & Ireland & Italy & Netherlands & Sweden & $\begin{array}{l}\text { United } \\
\text { Kingdom }\end{array}$ & $\begin{array}{l}\text { United } \\
\text { States }\end{array}$ \\
\hline 1973 & 0.2345 & 0.2172 & 0.2029 & 0.0848 & 0.0934 & 0.1477 & 0.0663 & 0.1163 & 0.4627 & 0.1699 & 0.1202 & 0.3125 \\
\hline 1974 & 0.2473 & 0.2286 & 0.1966 & 0.0995 & 0.0890 & 0.1421 & 0.0654 & 0.0935 & 0.3809 & 0.1756 & 0.1158 & 0.3079 \\
\hline 1975 & 0.3165 & 0.2280 & 0.2287 & 0.1195 & 0.1005 & 0.1670 & 0.1056 & 0.1268 & 0.4378 & 0.2141 & 0.1685 & 0.3103 \\
\hline 1976 & 0.3269 & 0.1909 & 0.3071 & 0.1139 & 0.1105 & 0.1798 & 0.0937 & 0.0990 & 0.4777 & 0.2259 & 0.1805 & 0.2972 \\
\hline 1977 & 0.3002 & 0.1999 & 0.3416 & 0.1184 & 0.1315 & 0.1873 & 0.1224 & 0.1264 & 0.4638 & 0.2513 & 0.2005 & 0.3133 \\
\hline 1978 & 0.3544 & 0.2643 & 0.4092 & 0.1511 & 0.1586 & 0.2443 & 0.1589 & 0.1412 & 0.4228 & 0.2785 & 0.2286 & 0.3585 \\
\hline 1979 & 0.3391 & 0.1956 & 0.3894 & 0.1665 & 0.2041 & 0.3092 & 0.1602 & 0.1581 & 0.4226 & 0.2853 & 0.2508 & 0.4162 \\
\hline 1980 & 0.2661 & 0.1805 & 0.3366 & 0.1653 & 0.2237 & 0.3060 & 0.1535 & 0.1872 & 0.3138 & 0.3148 & 0.3138 & 0.2562 \\
\hline 1981 & 0.1682 & 0.2227 & 0.1646 & 0.1141 & 0.1486 & 0.2207 & 0.1286 & 0.1336 & 0.3919 & 0.3201 & 0.3109 & 0.2361 \\
\hline 1982 & 0.2123 & 0.2654 & 0.2580 & 0.1281 & 0.1510 & 0.2299 & 0.1455 & 0.1453 & 0.3782 & 0.3186 & 0.2809 & 0.2633 \\
\hline 1983 & 0.2698 & 0.2193 & 0.2508 & 0.1226 & 0.1180 & 0.2137 & 0.1329 & 0.1592 & 0.4420 & 0.2275 & 0.2141 & 0.1159 \\
\hline 1984 & 0.2463 & 0.3651 & 0.2226 & 0.1456 & 0.1320 & 0.2200 & 0.1425 & 0.1397 & 0.3836 & 0.2975 & 0.2187 & 0.2382 \\
\hline 1985 & 0.2560 & 0.3404 & 0.2083 & 0.1657 & 0.1575 & 0.2279 & 0.1032 & 0.1481 & 0.3108 & 0.2183 & 0.1916 & 0.3756 \\
\hline 1986 & 0.4026 & 0.5292 & 0.3295 & 0.1869 & 0.1682 & 0.3092 & 0.1136 & 0.2034 & 0.5099 & 0.3221 & 0.2484 & 0.5781 \\
\hline 1987 & 0.4722 & 0.4427 & 0.3371 & 0.2114 & 0.2012 & 0.3438 & 0.1810 & 0.2348 & 0.5707 & 0.3519 & 0.2761 & 0.6276 \\
\hline 1988 & 0.4920 & 0.4522 & 0.3284 & 0.2270 & 0.1818 & 0.3142 & 0.2069 & 0.2052 & 0.5382 & 0.3977 & 0.2536 & 0.5579 \\
\hline 1989 & 0.5894 & 0.6113 & 0.3381 & 0.2228 & 0.1610 & 0.3447 & 0.2034 & 0.2248 & 0.5857 & 0.4545 & 0.2909 & 0.7505 \\
\hline 1990 & 0.6465 & 0.6382 & 0.4304 & 0.2248 & 0.1631 & 0.3908 & 0.2154 & 0.2261 & 0.6436 & 0.5681 & 0.3196 & 0.8216 \\
\hline 1991 & 0.6046 & 0.5696 & 0.2467 & 0.2989 & 0.1793 & 0.3154 & 0.2129 & 0.2380 & 0.6410 & 0.4646 & 0.3740 & 0.7644 \\
\hline 1992 & 0.6635 & 0.5525 & 0.2907 & 0.2631 & 0.1935 & 0.3851 & 0.2748 & 0.2555 & 0.6508 & 0.4091 & 0.4155 & 0.9477 \\
\hline 1993 & 0.7023 & 0.5901 & 0.4037 & 0.1952 & 0.2767 & 0.4065 & 0.2737 & 0.2275 & 0.5543 & 0.4026 & 0.3674 & 0.8883 \\
\hline 1994 & 0.7719 & 0.6520 & 0.4405 & 0.2522 & 0.3352 & 0.4621 & 0.3146 & 0.2690 & 0.6758 & 0.4294 & 0.3782 & 0.9697 \\
\hline 1995 & 0.7100 & 0.7963 & 0.3904 & 0.3332 & 0.3256 & 0.5366 & 0.2536 & 0.3245 & 0.7173 & 0.4377 & 0.3839 & 0.7872 \\
\hline 1996 & 0.7923 & 0.8452 & 0.5308 & 0.3235 & 0.4221 & 0.5601 & 0.2896 & 0.4217 & 0.7048 & 0.4701 & 0.3971 & 1.0000 \\
\hline 1997 & 0.7608 & 0.8067 & 0.5017 & 0.3258 & 0.4042 & 0.5438 & 0.2569 & 0.4280 & 0.5424 & 0.4614 & 0.3882 & 0.9153 \\
\hline 1998 & 0.7724 & 0.6580 & 0.4957 & 0.2889 & 0.3873 & 0.6046 & 0.3194 & 0.4659 & 0.5993 & 0.4464 & 0.3814 & 0.9392 \\
\hline 1999 & 0.6798 & 0.5775 & 0.4562 & 0.3010 & 0.3667 & 0.5491 & 0.3010 & 0.4574 & 0.5694 & 0.3362 & 0.4258 & 0.8095 \\
\hline 2000 & 0.5898 & 0.6051 & 0.3489 & 0.2858 & 0.3910 & 0.4348 & 0.2680 & 0.3917 & 0.5261 & 0.3575 & 0.3633 & 0.8753 \\
\hline 2001 & 0.6424 & 0.7454 & 0.3349 & 0.2967 & 0.4698 & 0.4326 & 0.2298 & 0.3827 & 0.5585 & 0.3290 & 0.4047 & 0.9379 \\
\hline 2002 & 0.5940 & 0.5604 & 0.3481 & 0.3199 & 0.5249 & 0.4884 & 0.2883 & 0.4177 & 0.5366 & 0.3176 & 0.5153 & 0.8838 \\
\hline
\end{tabular}

input prices. Rapid wage increases in the European countries during the 1970s and a declining dollar sent wages rates in the European countries above the U.S. level. But the subsequent appreciation of the dollar resulted in a decline in relative wage rates. By 2002 the wage rate in Belgium had fallen to $67 \%$ of the U.S. wage rate. The relative wage in Ireland in 2002 was only $33 \%$ of the U.S. level.

Our international comparisons of relative output and input prices show, first, that U.S. agriculture has been more competitive than its European counterparts throughout the period
1973-2002, except for the years 1973-1974 and 1983-1985. Second, lower costs of materials, capital, and land inputs contributed to U.S. international competitiveness for most of this period.

\section{Relative productivity levels}

In this section, we estimate relative levels of productivity in agriculture for the 11 European countries and the United 
Table 7

Total factor productivity relative to the 1996 level for the United States

\begin{tabular}{|c|c|c|c|c|c|c|c|c|c|c|c|c|}
\hline Year & Belgium & Denmark & Germany & Greece & Spain & France & Ireland & Italy & Netherlands & Sweden & $\begin{array}{l}\text { United } \\
\text { Kingdom }\end{array}$ & $\begin{array}{l}\text { United } \\
\text { States }\end{array}$ \\
\hline 1973 & 0.6802 & 0.5343 & 0.4609 & 0.3469 & 0.3259 & 0.4806 & 0.3609 & 0.4712 & 0.7476 & 0.2916 & 0.4710 & 0.5730 \\
\hline 1974 & 0.7018 & 0.6380 & 0.4865 & 0.3643 & 0.3323 & 0.4759 & 0.3900 & 0.4539 & 0.7850 & 0.3235 & 0.5014 & 0.5601 \\
\hline 1975 & 0.6461 & 0.5558 & 0.4437 & 0.3769 & 0.3447 & 0.4664 & 0.4053 & 0.4740 & 0.7433 & 0.3162 & 0.4864 & 0.6047 \\
\hline 1976 & 0.6037 & 0.5212 & 0.4730 & 0.3779 & 0.3707 & 0.4609 & 0.3835 & 0.4287 & 0.7243 & 0.3222 & 0.4673 & 0.5944 \\
\hline 1977 & 0.6662 & 0.5696 & 0.5136 & 0.3655 & 0.3889 & 0.4583 & 0.4113 & 0.4340 & 0.7285 & 0.3363 & 0.4959 & 0.6434 \\
\hline 1978 & 0.6837 & 0.5525 & 0.5306 & 0.3939 & 0.4190 & 0.4846 & 0.4091 & 0.4336 & 0.7312 & 0.3499 & 0.5161 & 0.6275 \\
\hline 1979 & 0.6705 & 0.5391 & 0.5496 & 0.3873 & 0.4422 & 0.5139 & 0.3825 & 0.4393 & 0.7361 & 0.3556 & 0.5189 & 0.6569 \\
\hline 1980 & 0.6707 & 0.5407 & 0.5456 & 0.4294 & 0.5063 & 0.5127 & 0.4015 & 0.4519 & 0.7297 & 0.3722 & 0.5444 & 0.6232 \\
\hline 1981 & 0.6838 & 0.5818 & 0.5524 & 0.4284 & 0.4516 & 0.5144 & 0.3937 & 0.4386 & 0.7653 & 0.3996 & 0.5485 & 0.6974 \\
\hline 1982 & 0.6916 & 0.6236 & 0.5920 & 0.4457 & 0.4857 & 0.5598 & 0.4229 & 0.4478 & 0.7851 & 0.4304 & 0.5617 & 0.7203 \\
\hline 1983 & 0.6865 & 0.5935 & 0.5868 & 0.4222 & 0.5170 & 0.5462 & 0.4310 & 0.4805 & 0.7915 & 0.4229 & 0.5507 & 0.6200 \\
\hline 1984 & 0.7202 & 0.6954 & 0.6036 & 0.4411 & 0.5759 & 0.5654 & 0.4743 & 0.4618 & 0.7891 & 0.4725 & 0.5954 & 0.7389 \\
\hline 1985 & 0.7169 & 0.6834 & 0.5845 & 0.4552 & 0.6087 & 0.5760 & 0.4671 & 0.4716 & 0.7776 & 0.4655 & 0.5731 & 0.7894 \\
\hline 1986 & 0.7332 & 0.7071 & 0.5951 & 0.4667 & 0.5462 & 0.5834 & 0.4424 & 0.4833 & 0.8181 & 0.4731 & 0.5720 & 0.7864 \\
\hline 1987 & 0.7138 & 0.6720 & 0.5758 & 0.4716 & 0.6066 & 0.5961 & 0.4673 & 0.4925 & 0.8041 & 0.4483 & 0.5714 & 0.8132 \\
\hline 1988 & 0.7313 & 0.7219 & 0.5836 & 0.4944 & 0.6422 & 0.5991 & 0.4777 & 0.4613 & 0.8302 & 0.4600 & 0.5631 & 0.7832 \\
\hline 1989 & 0.7394 & 0.7571 & 0.5921 & 0.5112 & 0.6057 & 0.6040 & 0.4505 & 0.4794 & 0.8502 & 0.4939 & 0.5780 & 0.8535 \\
\hline 1990 & 0.7704 & 0.7722 & 0.6718 & 0.4516 & 0.6331 & 0.6206 & 0.5079 & 0.4504 & 0.8858 & 0.5244 & 0.5795 & 0.8769 \\
\hline 1991 & 0.7748 & 0.7801 & 0.5960 & 0.5503 & 0.6320 & 0.6059 & 0.5160 & 0.4886 & 0.8961 & 0.5079 & 0.5873 & 0.8774 \\
\hline 1992 & 0.8339 & 0.7520 & 0.6202 & 0.5378 & 0.6412 & 0.6468 & 0.5485 & 0.4944 & 0.9061 & 0.4895 & 0.5951 & 0.9550 \\
\hline 1993 & 0.8408 & 0.8017 & 0.6204 & 0.5157 & 0.6453 & 0.6378 & 0.5254 & 0.5154 & 0.9142 & 0.5225 & 0.5792 & 0.9126 \\
\hline 1994 & 0.8025 & 0.7998 & 0.6337 & 0.5593 & 0.6418 & 0.6444 & 0.5239 & 0.5467 & 0.9349 & 0.5181 & 0.5810 & 0.9969 \\
\hline 1995 & 0.8010 & 0.8124 & 0.6460 & 0.5750 & 0.5966 & 0.6569 & 0.5258 & 0.5788 & 0.9395 & 0.5394 & 0.5681 & 0.9276 \\
\hline 1996 & 0.8135 & 0.8135 & 0.6570 & 0.5704 & 0.7310 & 0.6799 & 0.5483 & 0.6139 & 0.9312 & 0.5676 & 0.5637 & 1.0000 \\
\hline 1997 & 0.8176 & 0.8168 & 0.6660 & 0.5903 & 0.7734 & 0.6874 & 0.5548 & 0.6358 & 0.9029 & 0.5865 & 0.5679 & 1.0048 \\
\hline 1998 & 0.8481 & 0.8407 & 0.6804 & 0.6134 & 0.7744 & 0.6984 & 0.5543 & 0.6659 & 0.9417 & 0.5710 & 0.5791 & 1.0085 \\
\hline 1999 & 0.8712 & 0.8512 & 0.7140 & 0.6294 & 0.7245 & 0.7127 & 0.5498 & 0.7146 & 0.9688 & 0.5731 & 0.5962 & 1.0061 \\
\hline 2000 & 0.8733 & 0.8504 & 0.6936 & 0.6348 & 0.7885 & 0.7085 & 0.5719 & 0.7013 & 0.9736 & 0.5898 & 0.6160 & 1.0449 \\
\hline 2001 & 0.8331 & 0.8536 & 0.6664 & 0.6361 & 0.8163 & 0.6908 & 0.5729 & 0.6991 & 0.9537 & 0.5859 & 0.5920 & 1.0392 \\
\hline 2002 & 0.8720 & 0.8624 & 0.6945 & 0.6351 & 0.8783 & 0.7138 & 0.5924 & 0.6836 & 0.9489 & 0.5989 & 0.6328 & 1.0476 \\
\hline
\end{tabular}

States for the period 1973-2002. Ball et al. (2001) have reported relative productivity levels for nine of the 11 European countries and the United States for the period 1973-1993. In 1973, six European countries had higher levels of productivity than the United States. The United States closed the gap with two of these countries during the sample period. However, differences in productivity levels between four of the European countries-Belgium, Denmark, France, and the Netherlandsand the United States remained at the end of the period in 1993.

In order to extend the results of Ball et al. (2001) through 2002 we must take note of the following revisions of the data. First, the measure of output in the present study includes the value of services, such as machine hire. While accounting for a relatively small share of total output this series exhibits very rapid growth. Second, our measure of capital input reflects subsidies on purchases of new capital goods (see note 15). We used this information to improve our estimates of the user cost of capital. Finally, we have compiled regionally disaggregated data on land values and characteristics that reflect land quality. These data allow us to estimate hedonic price indexes for land that reflect differences in land quality across countries.

The revisions of the data have resulted in substantial changes in the rank ordering of countries from that presented in Ball et al.
(2001). As can be seen in Table 7, only two countries-Belgium and the Netherlands - had higher levels of productivity than the United States in 1973. Moreover, the United States had closed the gaps in productivity by the early 1990s.

Sweden and Spain were the only European countries to achieve faster rates of productivity growth in agriculture than did the United States. Most remarkable was the performance of Spain. Spain began the period in 1973 with the second lowest relative level of total factor productivity of any European country, but had overtaken Greece by 1977, Ireland by 1978, Italy by 1979 , France by 1984, Germany and the United Kingdom by 1985 , and Belgium and Denmark by 2002 .

There are several likely explanations for Spain's rapid productivity growth. The first is technological "catch-up" by initially backward countries. The idea is that imitation is less costly than innovation, so that countries initially lagging behind the technology leaders experience faster improvements in technology than do the leaders. Furthermore, the rate of catchup should accelerate as these countries become more integrated with the rest of Europe.

A second factor is capital deepening. Of the 11 European countries, only Denmark, France, and Ireland had faster rates of growth of capital per unit of labor than did Spain. 

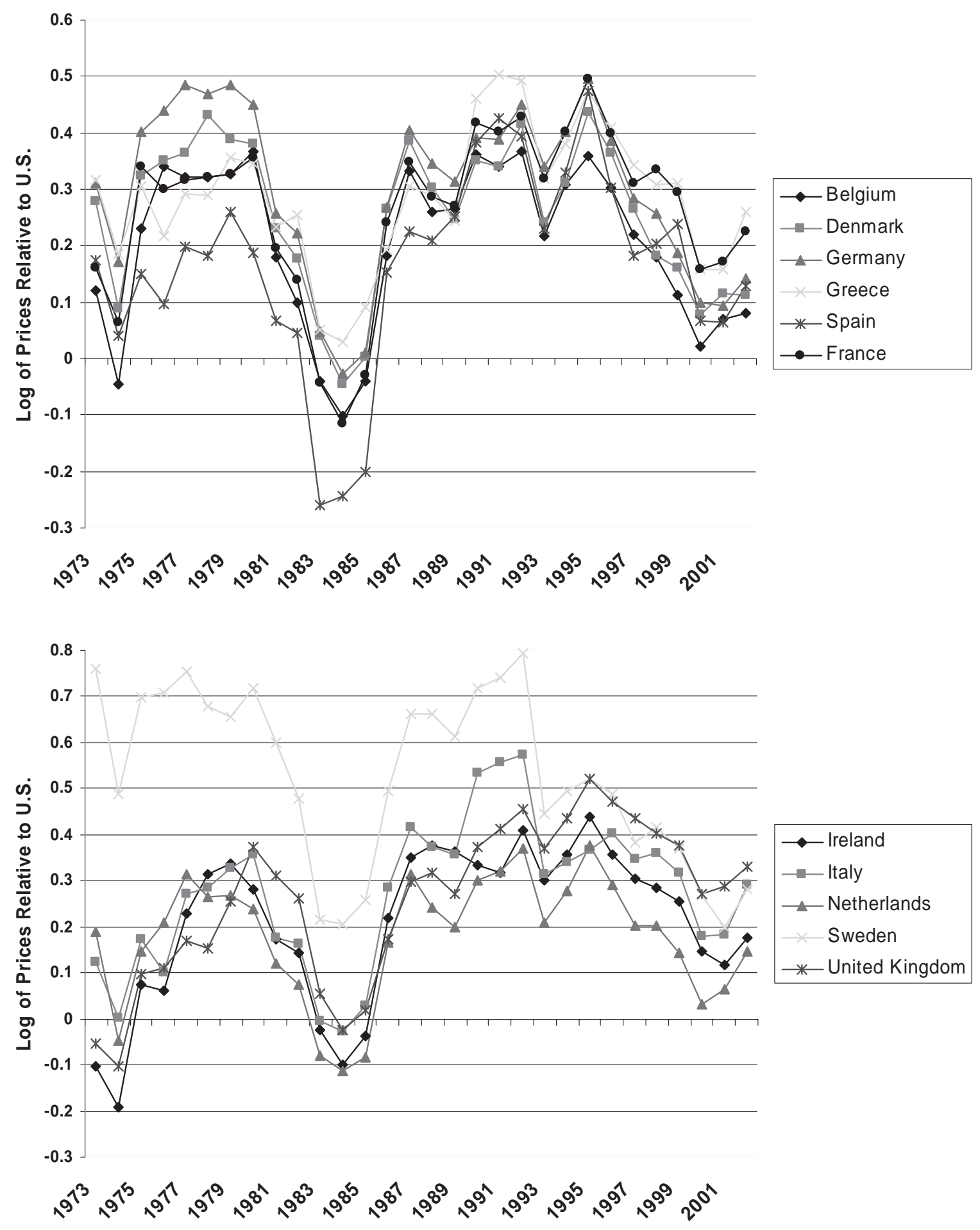

Fig. 1. Trends of differences in relative output prices denominated in dollars.

Ball et al. (2001) find this to be an important factor in determining the speed of convergence of productivity. Third, it can be argued that integration in the European Union has led to increased specialization in production of goods that are competitive in export markets. Mora and San Juan (2004) find that those regions initially specializing in production for export have increased their share of total output since Spain's joining of the European Union. ${ }^{22}$

\footnotetext{
${ }^{22}$ Spain's impressive productivity performance was not limited to agriculture. Looking at rates of productivity growth across sectors for the 1960-2000 period, Caselli and Tenreyro (2005) find that labor productivity convergence
} 


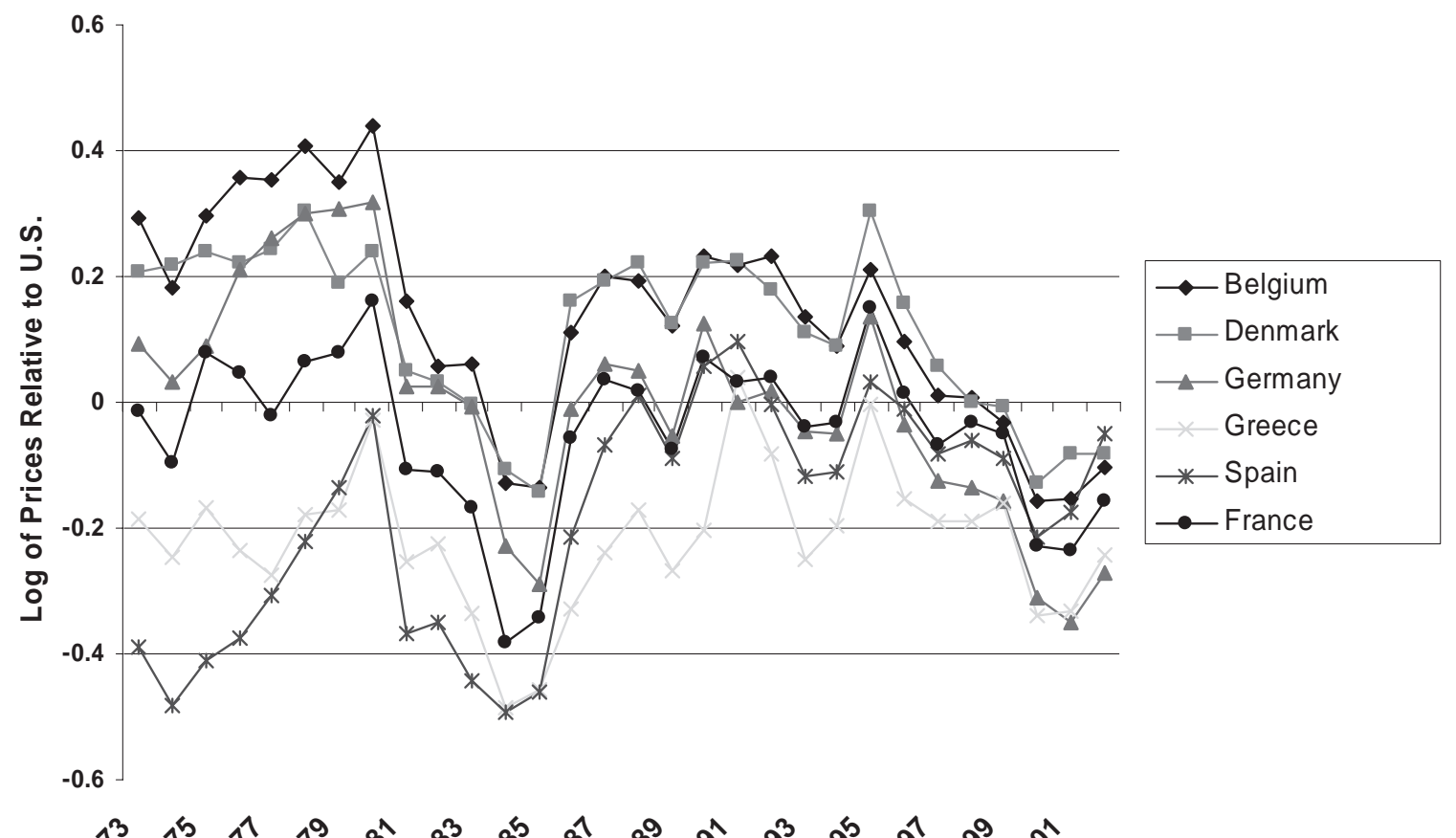

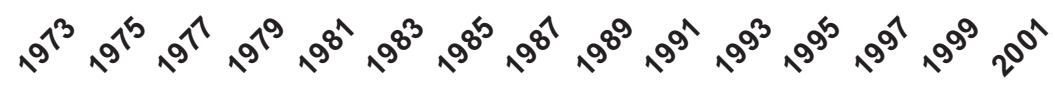

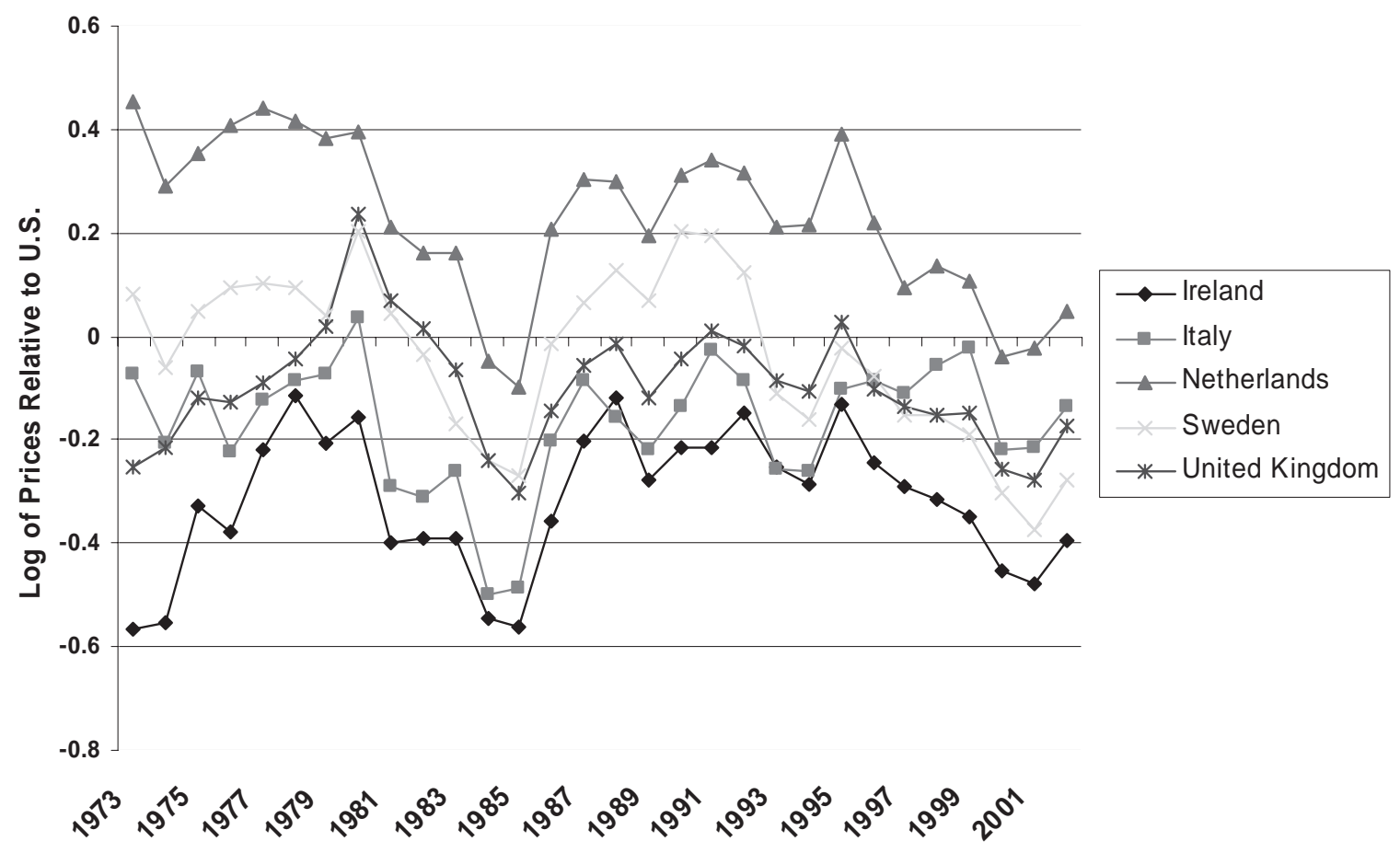

Fig. 2. Trends of differences in relative input prices denominated in dollars.

in Spain was driven both by a reallocation of labor from agriculture to more productive sectors and by catching-up of labor productivity within sectors. In contrast, convergence of labor productivity in the other lagging countries was mainly due to the reallocation of labor across sectors, while the contribution of within-industry catch-up to overall labor productivity convergence was actually negative.

\section{International competitiveness}

Finally, we turn to international competitiveness of European and U.S. agriculture. We can account for movements in relative prices of output in the 12 countries by changes in relative input prices and changes in relative productivity levels. Fig. 1 

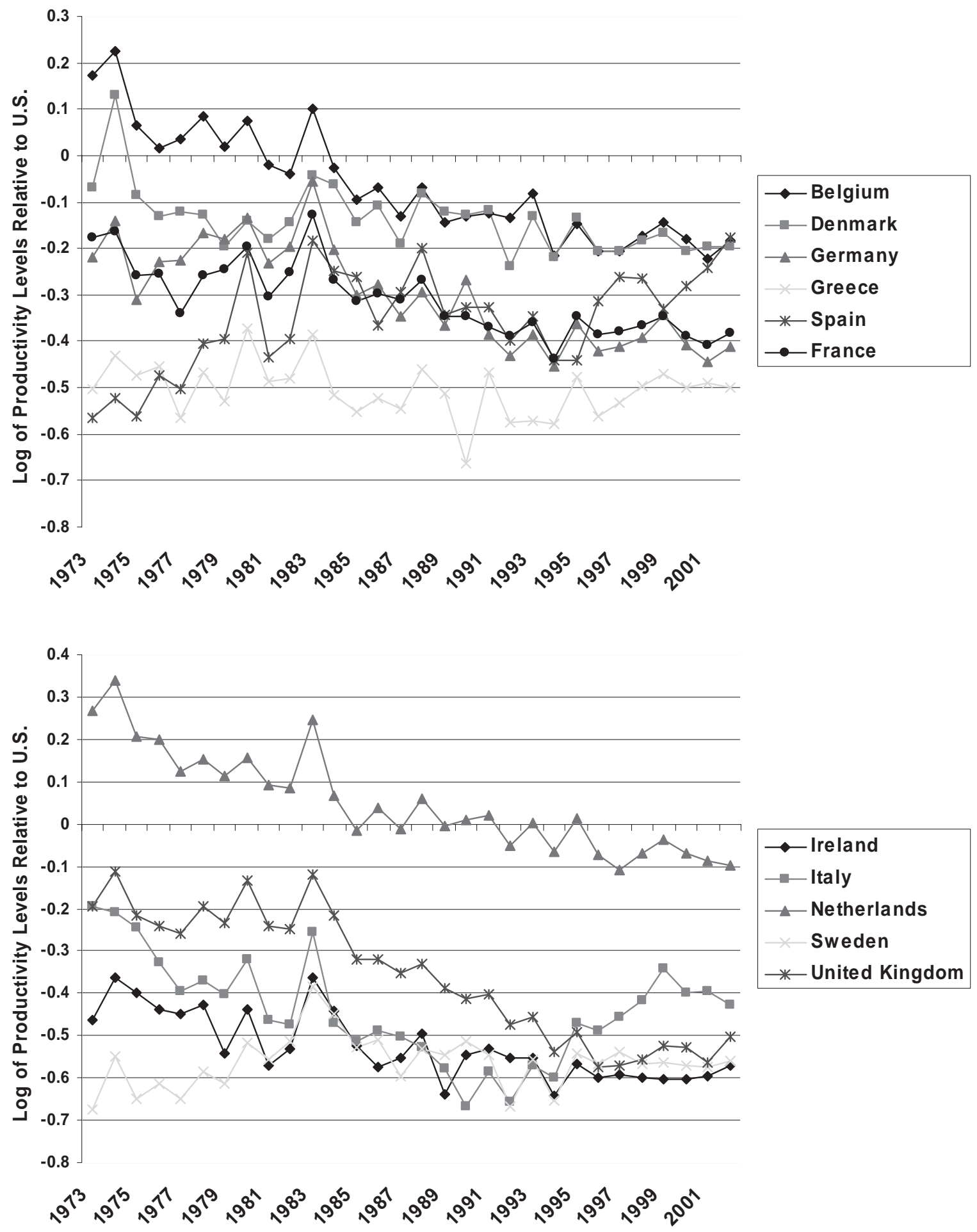

Fig. 3. Trends of differences in relative levels of productivity.

shows the relative price of output in the 11 European countries expressed in dollars. We have expressed these prices in logarithmic form so that a positive difference implies that the output price in the comparison country is above the U.S. price, while a negative difference implies a higher price in the United States.
In Figs. 2 and 3, we show indexes of relative input prices and relative levels of productivity.

In the 1970s, output prices in the European countries were above the U.S. price level, due primarily to lower levels of productivity. Although lower labor costs in the European countries 
helped to reduce relative prices of output, they were totally offset by lower levels of productivity in all the European countries except Belgium and the Netherlands. These two countries had higher levels of productivity than the United States in the 1970s, but they faced substantially higher prices for capital and land inputs.

The international competitiveness of European agriculture improved during the early 1980s in spite of productivity gains in the United States. This was because of more rapid increases in the costs of capital and land inputs in the United States and the appreciation of the dollar since 1980.

Output prices in the European countries increased relative to the United States after 1984. A weaker dollar resulted in higher prices of materials, capital, and land inputs in the European countries. Slower growth of productivity in the European countries further eroded their international competitiveness.

The upward trend in relative output prices was reversed after 1995, notwithstanding the increasing U.S. productivity advantage. More rapid increases in the prices of capital and materials inputs and the appreciation of the dollar pushed output prices in the United States higher.

\section{Summary and conclusions}

The deterioration in the terms of trade with the European Union raises the specter of declining international competitiveness of U.S. agriculture. We address the competitiveness of agriculture in the European Union and United States by providing a formal definition of the concept of competitiveness and relating it to the more conventional concept of relative productivity.

The most intuitive concept of competitiveness is that of price competitiveness. In this study, we calculate relative prices for 11 member states of the European Union and the United States for the period 1973-2002. We assume that markets are perfectly competitive and in long-run equilibrium, so that the observed price always equals average total cost, as measured by the cost dual to the production function. This assumption is used in our calculation of relative competitiveness and productivity gaps between the European Union and the United States and in our decomposition of relative price movements between changes in relative input prices and changes in relative productivity levels. $^{23}$

Our international comparisons of relative prices show that the United States was more competitive than its European counterparts throughout the period 1973-2002, except for the years 1973-1974 and 1983-1985. Our results also suggest that the relative productivity level was the most important factor in de-

\footnotetext{
${ }^{23}$ An alternative measure of price competitiveness, also assuming perfect competition but postulating short-run equilibrium rather than immediate adjustment of capital input to optimal levels, is derived by Conrad (1987), who compares the resulting productivity gaps with those based on long-run equilibrium.
}

termining international competitiveness. Over time, however, changes in international competitiveness were strongly influenced by variations in exchange rates through their impact on relative input prices. During the periods 1979-1984 and 19962001, the strengthening dollar helped the European countries improve their competitive position, even as their relative productivity performance lagged.

Only two European countries-Sweden and Spainachieved faster rates of productivity growth in agriculture than did the United States. Most impressive was the performance of Spain. Spain began the period in 1973 with the second lowest relative level of total factor productivity of any European country, but had overtaken Greece by 1977 , Ireland by 1978, Italy by 1979 , France by 1984 , Germany and the United Kingdom by 1985 , and Belgium and Denmark by 2002 . There are several likely explanations for Spain's rapid productivity growth. First is what Gerschenkron (1952) termed the advantages of relative backwardness; those countries that were particularly far behind the technology leaders had the most to gain from diffusion of technical information and proceeded to grow most rapidly. A second is capital deepening. Ball et al. (2001) find this to be an important factor in determining the speed of convergence of productivity. Finally, Caselli and Tenreyro (2005) emphasize resource reallocations (particularly labor) among sectors as contributing to rapid productivity growth.

\section{References}

Arnade, C., 1995. Productivity Growth in 76 Countries. Economic Research Service, US Department of Agriculture, Washington, DC.

Ball, V.E., Bureau, J.-C., Butault, J.-P., Nehring, R., 2001. Levels of farm sector productivity: An international comparison. J. Product. Analysis 15, 529.

Beutel, J., 1998. Capital Stock Data for the European Union. Vol. 17. Report to the Statistical Office of the European Communities, Luxembourg.

Caselli, F., Tenreyro, S., January 2005. Is Poland the Next Spain? Center for Economic Performance Discussion Paper No. 668, London.

Caves, D.W., Christensen, L.R., Diewert, W.E., 1982. Multilateral comparisons of output, input, and productivity using superlative index numbers. Econ. Journal 92, 73-86.

Coelli, T., Prasada Rao, D.S., 2003. Total Factor Productivity Growth in Agriculture: A Malmquist Index Analysis of 93 Countries. Centre for Efficiency and Productivity Analysis, University of Queensland, Brisbane, Australia.

Conrad, K., 1987. Productivity and Cost Gaps in Five Manufacturing Industries in U.S., Japan, and Germany. In: Eichhorn, W. (Ed.), Measurement in Economics. Physica Verlag, Heidelberg/New York, pp. 725-750.

Diewert, W.E., 1976. Exact and superlative indexes. J. Econometrics 4, 115146.

Diewert, W.E., 1992. The measurement of productivity. Bull. Econ. Res. 44, 163-198.

Drechsler, L., 1973. Weighting of index numbers in multilateral international comparisons. Rev. Income Wealth 19, 17-34.

Eswaren, H., Beinroth, F., Reich, P., 2003. A Global Assessment of Land Quality. In: Weibe, K. (Ed.), Land Quality, Agricultural Productivity, and Food Security. Edward Elgar, Cheltenham, UK.

Eurostat, 2000. Manual on the Economic Accounts for Agriculture and Forestry. Eurostat, Luxembourg. 
Gerschenkron, A., 1952. Economic Backwardness in Historical Perspective. In: Hoselitz, B.F. (Ed.), The Progress of Underdeveloped Areas. University of Chicago Press, Chicago.

Gopinath, M., Arnade, C., Shane, M., Roe, T., 1997. Agricultural competitiveness: The case of the United States and major European countries. Agric. Econ. 16, 99-109.

Jorengenson, D.W., Griliches, Z., 1967. The explanation of productivity change. Rev. Econ. Stud. 34, 249-283.

Jorgenson, D.W., Nishimizu, M., 1978. U.S. and Japanese economic growth, 1952-1974: An international comparison. Econ. J. 83, 707-726.

Jorgenson, D.W., Nishimizu, M., 1981. International Differences in Levels of Technology: A Comparison Between U.S. and Japanese industries. In: International Roundtable Congress Proceedings. Institute of Statistical Mathematics, Tokyo.

Mora, R., San Juan, C., 2004. Geographical specialization in Spanish agriculture before and after integration in the European Union. Regional Sci. Urban Econ. 34, 309-320.

Organization for Economic Cooperation and Development, 1999. Purchasing Power Parities and Real Expenditures. OECD, Paris.
Penson, J.B., Hughes, D.W., Nelson, G.L., 1977. Measurement of capacity depreciation based on engineering data. Am. J. Agric. Econ. 35, 321329.

Romain, R., Penson, J.B., Lambert, R., 1987. Capacity depreciation, implicit rental prices, and investment demand for farm tractors in Canada. Canadian J. Agric. Econ. 35, 373-378.

Rosen, S.M., 1974. Hedonic prices and implicit markets: Product differentiation in pure competition. J. Pol. Econ. 82, 34-55.

Samuelson, P.A., 1953. Prices of factors and goods in general equilibrium. Rev. Econ. Stud. 21, 1-20.

Shephard, R.W., 1953. Cost and Production Functions. Princeton University Press, Princeton, NJ.

Shephard, R.W., 1970. Theory of Cost and Production Functions. Princeton University Press, Princeton, NJ.

Shi, U.J., Phipps, T.T., Colyer, D., 1997. Agricultural land values under urbanizing influences. Land Econ. 73, 90-100.

U.S. Department of Commerce, Bureau of Economic Analysis, 2003. Fixed Reproducible Tangible Wealth in the United States. U.S. Department of Commerce, Washington, DC. 